IZA DP No. 6529

What Effects Do Macroeconomic Conditions Have on

Families' Time Together?

Melinda Sandler Morrill

Sabrina Wulff Pabilonia

April 2012 


\title{
What Effects Do Macroeconomic Conditions Have on Families' Time Together?
}

\author{
Melinda Sandler Morrill \\ North Carolina State University \\ Sabrina Wulff Pabilonia \\ U.S. Bureau of Labor Statistics \\ and IZA
}

Discussion Paper No. 6529

April 2012

IZA

P.O. Box 7240

53072 Bonn

Germany

Phone: +49-228-3894-0

Fax: +49-228-3894-180

E-mail: iza@iza.org

Any opinions expressed here are those of the author(s) and not those of IZA. Research published in this series may include views on policy, but the institute itself takes no institutional policy positions.

The Institute for the Study of Labor (IZA) in Bonn is a local and virtual international research center and a place of communication between science, politics and business. IZA is an independent nonprofit organization supported by Deutsche Post Foundation. The center is associated with the University of Bonn and offers a stimulating research environment through its international network, workshops and conferences, data service, project support, research visits and doctoral program. IZA engages in (i) original and internationally competitive research in all fields of labor economics, (ii) development of policy concepts, and (iii) dissemination of research results and concepts to the interested public.

IZA Discussion Papers often represent preliminary work and are circulated to encourage discussion. Citation of such a paper should account for its provisional character. A revised version may be available directly from the author. 


\section{ABSTRACT}

\section{What Effects Do Macroeconomic Conditions Have on Families' Time Together?*}

We examine family time together using data from the 2003-2010 American Time Use Survey combined with Bureau of Labor Statistics data on state-level unemployment rates. Couple time together is U-shaped; while fathers spend more time engaging in enriching childcare activities without a spouse present as the unemployment rate rises. Patterns are similar for dual-earner couples, but appear concentrated among demographic groups most affected by recessions. We also find that mothers are less likely to work standard hours and more likely to work on weekends as employment crises deepen, which is consistent with both sets of results for family time together.

JEL Classification: $\quad$ D1, J22, J12, E32

Keywords: unemployment, time use, time together, Great Recession, nonstandard work hours

Corresponding author:

Sabrina Wulff Pabilonia

U.S. Bureau of Labor Statistics

2 Massachusetts Ave, NE

Washington, DC 20212

USA

E-mail: Pabilonia.Sabrina@bls.gov

\footnotetext{
${ }^{*}$ All views expressed in this paper are those of the authors and do not necessarily reflect the views or policies of the U.S. Bureau of Labor Statistics. The authors would like to thank Dhaval Dave, Michael Giandrea, Jennifer Hook, David Ribar, Almudena Sevilla-Sanz, Jay Stewart, and Jennifer Ward-Batts for their useful suggestions. This paper benefited from comments from participants at the 2010 International Association of Time Use Researchers' Conference, the 2011 International Perspectives on Time Use Conference at the University of Maryland, and the 2011 Southern Economic Association Annual Meeting.
} 


\section{Introduction}

During periods of macroeconomic decline, families may adjust their time spent together, which in turn may affect both marital stability and child well-being. Although periods of high unemployment are associated with economic hardships in families, recent work suggests that there may be some positive effects for families, as well. In the health economics literature, Ruhm (2000) and Tapia Granados (2005) suggest that mortality rates drop during recessions. Other recent studies find a decline in divorce rates during periods of higher unemployment (Amato and Beattie, 2011; Hellerstein and Morrill, 2011; Schaller, 2012).

Although previous work has suggested a link between business cycles and demographic outcomes, the mechanisms through which the economy might affect families are not clear. In a study of the effect of local business cycles on individuals' time allocation decisions using preGreat Recession time use data, Burda and Hamermesh (2010) find that individuals experiencing unemployment reallocate the majority of their time toward leisure rather than household production. However, over all individuals experiencing a temporary increase in local unemployment rates, they find that the reduction in market work is completely offset by an increase in household production. This suggests that local economic conditions affect the time use of individuals who directly experience job loss as well as those who remain employed. Gimenz-Nadal et al. (2010) find similar results using Spanish time use data. Using time use data including the Great Recession, Aguiar et al. (2011b) consider the average reductions in time spent in market work over the business cycle, including those who maintain employment. They find that of the foregone work hours about 30 to 40 percent are allocated to home production activities while about 50 percent are allocated to some type of leisure activity. 
In this paper, we seek to understand how additional time from reduced labor market activities over the business cycle translates into "family togetherness" in households with married or cohabitating couples with co-resident children. We use data from the 2003-2010 American Time Use Survey (ATUS) combined with U.S. Bureau of Labor Statistics data on state-level unemployment rates to capture local economic conditions, including the large negative employment effects of the Great Recession. We also include both state and year fixed effects, enabling us to identify from variation in state-level unemployment rates over time the relationship between state unemployment rates and family time together. We do not explicitly consider the effects of an individual's or spouse's job loss. ${ }^{1}$ However, we do explore whether our results differ for couples where both spouses are employed at the time of the survey (dualearner couples) and find nearly identical patterns.

The first outcome that we consider is the number of minutes a couple spends together. We then examine for mothers and fathers separately how total time spent with children and time spent in enriching activities with children varies over the business cycle. We find a U-shaped relationship between couples’ time together and the unemployment rate. One possible reason for the variation in time together is that a reduction in jobs with desirable work schedules during periods of economic contraction hinder the ability of couples to synchronize their time at work in order to spend time together (Halberg, 2003; Hamermesh, 2003), but at the highest unemployment rates, couples’ total hours may be significantly reduced allowing more time together. We find that when state unemployment rates are relatively high, mothers shift work

\footnotetext{
${ }^{1}$ Although considering the effects of employment shocks to households is of interest, unusually high or unusually low unemployment rates may affect families even if they do not themselves experience a change in employment status. Because job loss may not be exogenous to time use within the family, we believe that question would be better addressed using panel data.
} 
time from weekdays to weekends. On average, fathers, many of whom have lost their jobs or face reduced working time, spend additional time engaging their children alone in enriching childcare activities as the local unemployment rate increases. In addition, we find that there are substantial indirect effects of general economic conditions on families' time use, beyond the direct effects of individual job loss.

\section{Theoretical Motivation and the Great Recession}

There are many potential channels through which fluctuations in local labor market conditions might affect the amount of time that a family spends together, for both those families that experience job loss and those whose formal job status does not change. Furthermore, we argue that the relationship between a family's time together and local labor market conditions need not be linear, where economic decline always leads to an increase or decrease in time together regardless of levels.

For a couple or family to share time together, each individual must have some time available to spend in leisure (or joint home production). Furthermore, the family members must be able and willing to coordinate their schedules to enjoy that time together. If one family member experiences a job loss, this could result in a time windfall which that individual may choose to spend either in household production, leisure, or job search activities. Burda and Hamermesh (2010) and Gimenz-Nadal et al. (2010) find that, in general, the time windfall following job loss is spent in leisure activities rather than household production. However, for individual job loss to be associated with more family time together, it must also be the case that other family members are available to share in this newfound time. If other household members, particularly the spouse, must enter the labor market to compensate for lost income (i.e., an "added worker" effect), then we may, in fact, see a decline or no change in shared time. Şahin et 
al. (2010) find evidence that “added workers," generally women who have childcare responsibilities during the day, work at nonstandard hours to supplement family income, particularly during the recent Great Recession.

Research has demonstrated that work hours fluctuate over the business cycle, even for those who remain continuously employed. However, the direction and magnitude of the relationship seems to vary between different periods of a recession. Our identification strategy relies on differences in unemployment rates between states over time, which may mask any small changes in work hours. Kroll (2011) reports that in the current Great Recession, average weekly hours paid did not begin to fall dramatically until about six months into the recession, as dated by the National Bureau of Economic Research (NBER). Twelve months into the recession, the U.S. witnessed a drop in aggregate weekly hours paid that was larger than during the two previous recessions. However, salaried workers who are mostly paid for 40 hours may work increased unpaid overtime either to secure their jobs or because they are asked to pick up the work done by those let go in mass layoffs. Thus, the effects on hours worked across workers by pay status are ambiguous.

Besides fluctuations in total hours of work, there may also be changes in the timing of hours worked over the business cycle. Prior research on time use has found that spouses attempt to synchronize their work schedules and leisure time (Connelly and Kimmel, 2009; Hamermesh, 2002; Halberg, 2003; Jenkins and Osberg, 2005), but this may be less of an option when the labor market is tight and family members are working longer hours. In addition, during a recession, some workers will lose their jobs and may be more willing to accept new jobs that require workers to work at hours that do not allow spouses to synchronize their work schedules. 
In addition to having time available to spend together, individuals also must choose to share that leisure time. If periods of high unemployment lead to higher stress levels for the unemployed (Krueger and Mueller, 2010; Krueger and Mueller, 2012), then family members may avoid spending time together due to increased conflict. Several recent studies show that divorce rates fall during periods of economic decline (Amato and Beattie, 2011; Hellerstein and Morrill, 2011; Schaller, 2012). However, these studies do not necessarily imply that couples are happier or that they are spending more time together. Further, couples who are liquidity constrained by the recession may stay home and do lower cost activities with their families (e.g., Evans and Moore, 2011). In addition, as wages fall in recessionary times, the opportunity cost of time is lower and parents may choose to spend more time on time-intensive childcare. ${ }^{2}$

How we might anticipate business cycles affecting families’ time together on average is ambiguous theoretically. During periods of high unemployment, we expect to see more total hours of leisure for those who have lost a job or are continuously employed but working fewer hours, but this additional time is not necessarily spent with family. On the other hand, family members may have to take on additional work responsibilities during non-standard hours if the family is in financial distress, so this might lead to a reduction in time that family members could spend together. Families that become more income constrained during periods of macroeconomic decline could also spend more time at home and thus enjoy more shared leisure hours; on the other hand, families may also cease to engage in shared leisure outside the home, such as dining out or attending recreational activities together.

\footnotetext{
${ }^{2}$ Real hourly compensation in the non-farm business sector fell by 0.4 percent in 2008 relative to 2007 [U.S. Department of Labor, U.S. Bureau of Labor Statistics. 2011. Database of Major Sector Productivity and Cost Index. www.bls.govllpc, accessed November 13, 2011].
} 


\section{Time Use Data}

\section{Data and Sample}

The American Time Use Survey (ATUS) is the only ongoing survey of how people living in the United States spend their time. Therefore, it is the only time use survey that currently allows for the examination of the effects of business cycles on the behavior of individuals beyond their working time behavior. In 2003, the ATUS began surveying one individual aged 15 and older per household drawn from a subsample of households completing their final month of interviews in the Current Population Survey (CPS). Phone interviews for the ATUS were conducted two to five months following the final CPS interview. The ATUS updates employment information from the CPS for the respondent and their spouse/unmarried partner, but not for all household members. For the spouse's employment status, no distinction is made between being unemployed and being out of the labor force. In addition, a 24-hour time diary is collected beginning at 4 a.m. on the day prior to the interview. Respondents are asked to report their activities sequentially, the start and stop time of each activity, where the activity took place, and, for most activities, who was with them in the room or who accompanied them on an activity if they were not at home (with whom information was not collected for the following activities: sleeping, grooming, private activities, working, taking a class, refused to classify type, or can’t remember). Respondents were also asked to report secondary childcare of children who were under age 13, but no other secondary activities were reported initially. From 2006 to 2008, secondary eating and drinking activities were captured in a special module to the ATUS. Activities are coded by interviewers into one of 17 major time categories, with various secondtier and third-tier subcategories. 
Time diary data have the advantage over other survey questions asked about time over the last week (or usual activity) of being less subject to recall bias because of the shorter time horizon. The data are also less subject to aggregation bias (because respondents are asked to account for 1440 minutes of activities in the diary day) and are less subject to social desirability bias (Bianchi et al., 2006). One of the disadvantages of time diary data is that the data are highly variable due to capturing information on a single day, thus leading to reduced statistical power in regression analyses, especially for activities that occur infrequently. In 2003, 20,720 diaries were completed. In the following years, the sample surveyed was reduced and between 12,000 and 14,000 diaries were collected, with response rates over 50 percent in each year. We use pooled diaries from 2003 to 2010 and thus cover both an economic expansion and contraction and the beginning of another expansion. About half of the diaries were collected on weekdays and half on weekend days. Throughout this paper, we use the ATUS final weights to estimate means and coefficients. We use replicate weights to correct standard deviations for summary statistics as specified in the ATUS User’s Guide (see U.S. Department of Labor 2011, p. 36). In all regressions, we cluster standard errors by state.

For our analysis, we are interested in the time family members spend together and how that time changes over the business cycle. Our main results include data from a sample of heterosexual couples with co-resident children under the age of 19 and where both parents were aged 25-64. The sample construction is illustrated in Appendix Table A1. We exclude diaries that captured atypical days (those where the respondent reported either sleeping more than 20 hours or being ill for more than four hours on their diary day) (Juster, 1985). ${ }^{3}$ The parents could

\footnotetext{
${ }^{3}$ While not all respondents record activities for the full 1400 minutes in the diary day, respondents are automatically discarded by ATUS staff if their diaries contain fewer than five activities and are missing 180 or more minutes of recorded activities (low quality diaries). Failure to include all respondents in
} 
be married or cohabitating (only 4 percent of couples with children under the age of 19 are cohabitating). Our couple sample has 34,001 observations, which includes 18,066 mothers and 15,935 fathers.

\section{Family Time}

We examine time together as a family from parents’ perspectives, both time spent together as a couple and total time with children. ${ }^{4}$ Total time with children is a global measure of childcare and includes any time when the child is present; thus it combines parental leisure, parental home production, and parental investments (Aguiar et al., 2011a). Parents may be cooking, cleaning, or watching TV with their children present, but there is no meaningful interaction taking place. Therefore, we also consider time spent with children in enriching childcare activities. Enriching childcare includes educational time, such as help with homework and reading to children, as well as time playing and talking with any of their children. It also includes time socializing and attending events with children aged two and older, because parents record the time they spend enjoying activities with children differently for younger and older children (Pabilonia and Song, 2011; Stewart, 2010). ATUS activity codes used to define time in

analyses may bias results. Colman and Dave (2011) found that employed respondents are one percentage point less likely to report gaps due to vague activities. Thus, excluding respondents could lead to an understatement of the effects of the business cycle on behavior. Many researchers exclude those missing more than 60 minutes of time. Only 5 percent of our sample is missing more than this amount. Our main results excluding these individuals are virtually identical.

${ }^{4}$ We also have examined time in shared leisure activities with similar, but smaller less precise estimates. However, it is not straightforward to categorize activities into leisure time versus time spent in household production. We define shared leisure time similar to the main definition used by Aguiar and Hurst (2007), with a few exceptions such as the addition of religious activities that includes attendance at weddings. Shared leisure time includes the following activities: caring for lawn, garden and houseplants, animals and pets; eating and drinking; socializing; watching TV; relaxing and leisure; sports, exercise and recreation; telephone calls to family members and friends; and travel related to socializing, sports, or religious activities. 
enriching childcare are provided in Appendix Table A2. The main non-enriching activities include watching TV, traveling, shopping, and eating.

We examine time with mothers and fathers separately, as well as enriching time alone with children. If families are together at home, one parent may have a higher level of involvement with the children. In particular, a father may only be passively involved with children or interacting with the mother when the whole family is together. Indeed, previous research on childcare has assumed that when both parents are accompanying the child, it is actually the mother who is likely to assume the greatest responsibility for the children (Folbre et al. 2005). However, father time alone with children may be of particular importance for child development, especially for boys (Morgan et al. 1988). Therefore, we explore whether fathers' time with children in various enriching and non-enriching activities is affected by the business cycle. Furthermore, we estimate fathers' time with children for dual-earner couples only and separately by fathers' education level.

\section{Macroeconomic Conditions}

From the U.S. Bureau of Labor Statistics’ Local Area Unemployment Statistics, we obtain unemployment rates for 50 U.S. states plus the District of Columbia that can be linked to the ATUS respondents by the state in which they reside. These unemployment rates are available both monthly and yearly. We use an average of the 12 months ending in the interview month as our proxy for the current macroeconomic conditions. The unemployment rate is measured over 12 months, instead of a shorter period, in order to allow behavioral patterns to 
become more consistent and to minimize any potential effects of short-term fluctuations in the unemployment rate resulting from sampling error (Arkes and Klerman, 2009). ${ }^{5}$

Figure 1 shows the variation in the value of the mean, maximum, and minimum state unemployment rate for our couple sample by survey year, where the state unemployment rate is defined over the 12-month period ending in the survey month. The mean state yearly unemployment rate over the period of study is about 6.1 percent, with a minimum rate of 2.5 percent and a maximum rate of 14.9 percent. There is a dramatic rise in both the mean and maximum 12-month lagged unemployment rates in 2009, which are an average of unemployment rates over the 2008-2009 period. There was an additional increase in both the mean and the maximum state unemployment rate for 2010.

\section{Econometric Model and Results}

Our basic econometric model is as follows: ${ }^{6}$

Family Time $_{\text {ist }}=\alpha+\beta_{1} *$ Urate $_{\mathrm{s}, \mathrm{t}-1}+\beta_{2} *$ Urate $_{\mathrm{s}, \mathrm{t}-1}{ }^{2}+\gamma \mathrm{X}_{\text {ist }}+\delta_{\mathrm{s}}+\theta_{\mathrm{t}}+\varepsilon_{\text {ist }}$

where Family Time ist $_{\text {is }}$ the minutes spent together (or in some cases participation in an activity) of family $i$ living in state $s$ at time $t ;{ }^{7}$ Urate $_{s, t-1}$ is the state-level unemployment rate

\footnotetext{
${ }^{5}$ However, results using an average of only the prior three months are similar. As another robustness check, we used core-based statistical area (CBSA) unemployment rates for May 2004-2010 and metropolitan statistical area (MSA) unemployment rates prior to May 2004, which we could link to about 82 percent of the sample. Results for couple time together were, in general, similar, but smaller in magnitude and less precise. We also ran estimates using the employment-to-population ratio as a proxy for macroeconomic conditions. The effects were less precise, with the strongest results for subsamples most likely to be affected by the Great Recession. Estimates are available from the authors upon request.

${ }^{6}$ This specification is similar to those commonly used when exploring the relationship between demographic outcomes and the business cycle (see, e.g., Ruhm, 2000), except that here we model the unemployment rate as a quadratic. With state and year fixed effects, one is implicitly calculating deviations from the sample means. Instead, one might consider looking at changes in the unemployment rate rather than levels. However, to be consistent with the prior literature, we have chosen to model the unemployment rate in levels and to include both state and year fixed effects.

${ }^{7}$ A histogram of couples' time together is skewed to the left, suggesting that a logged dependent variable may be appropriate. Although log of minutes is not a common specification used in the time use
} 
averaged over the last twelve months ( $\mathrm{t}-1), \mathrm{X}_{\text {ist }}$ is a vector of observable individual and familylevel variables, $\alpha$ is a constant, $\delta$ 's are state fixed effects, and $\theta$ 's are year fixed effects. ${ }^{8} \varepsilon_{\text {ist }}$ is a stochastic disturbance term assumed to follow a normal distribution. The key coefficients of interest are $\beta_{1}$ and $\beta_{2}$, the effect of the unemployment rate on a family's time together, which capture the effect of within-state variation in macroeconomic conditions relative to other states. All models of time spent throughout the paper are estimated using ordinary least squares.

In our regression model (1), $\mathrm{X}_{\mathrm{i}}$ includes own and spouse’s age and age squared, and indicators for husband and wife education (high school dropout, some college, college, missing, with high school degree being the omitted category), race and ethnicity (non-Hispanic black, other, Hispanic, with non-Hispanic white being the omitted category), gender, age of youngest household child (infant, preschooler, elementary school aged, with high school aged being the omitted category), presence of household child older than age 18, lives with other adults (e.g. parent or sibling), cohabitating couple, gender composition of the children (all boy children, mixed gender children, with all girls being the omitted category), respondent lives in SMSA, and season. Appendix Table A3 includes means for most of the variables used in these analyses. Appendix Table A4 includes the full set of estimated coefficients for equation (1). ${ }^{9}$

literature, Pailhe and Solaz (2008) use this specification to examine the determinants of parents' time with children. Given that some couples never spend any time together on their diary day, we change the zeros to ones before estimating a specification where the dependent variable is logged. The results are similar and have not been presented here for brevity.

${ }^{8}$ Year fixed effects are included to capture any long run trends in time use, such as the documented increases in total leisure time pre-Great Recession and in father's time with children (Aguiar et al., 2011b; Guryan et al., 2008; Bianchi et al., 2006). We explored the sensitivity to omitting the year fixed effects. Time use changes slowly over time, but excluding the year fixed effects allows identification to come from the additional variation over the time period studied. The effects were smaller in magnitude, but the patterns were similar. Results are available upon request.

${ }^{9}$ As reported in Appendix Table A4, we find that females report significantly less time together with their spouse than do males. Although these are not the same couples, we would not expect their time together to be different (the observable characteristics, presented in Appendix Table A3, such as age and 
Figure 2 shows the unadjusted relationship between couples’ time together and local unemployment rates. The smallest number of minutes spent together in a day occurs during the period of lowest unemployment (2-4 percent), although in a test of equality of weighted means this is not statistically significantly lower than time spent together when the state unemployment rate is between 4 and 6 percent. When the unemployment rate is at its highest, 10 percent or greater, the average amount of time couples spend together is significantly higher than time spent together when the unemployment rate is between 4 and 6 percent (264.23 versus 248.96, significant at the 1 percent level).

Table 1 presents estimates from pooled cross-sections of the effect of the unemployment rate on couples' time together. ${ }^{10}$ The regression is estimated modeling the unemployment rate linearly and as a quadratic for the full sample, as specified in equation (1), including both state and year fixed effects. In row (A), we first consider all couples and find a U-shaped relationship. ${ }^{11}$ The unemployment rate is associated with a decline in couples' time together until the unemployment rate reaches around 8.7 percent, at which point couples' time together

education, are similar). However, it may be that males and females answer the "with whom" questions differently based upon activities that are participatory rather than just being present in the room. In addition, mothers report, on average, 25 activities on their diary while fathers report only 19 activities. There is other evidence that individuals in families answer survey questions differently. For example, Pabilonia (2001) found that parents and their teenage children within the same family differ in reports on how much of an allowance the teen receives.

${ }^{10}$ Zero time spent in a particular activity may be due to non-participation in that activity on all days, or participating on some days and not others. If family members spend time together at some point in time, and if the day, season, and year we observe the individual's time use is random, OLS will provide consistent estimates of the determinants of time use. To the extent that some parents may never spend time with their children, then OLS estimates may be biased.

${ }^{11}$ This relationship holds even if we exclude the observations in states with the lowest and highest unemployment rates (the analysis was done trimming $1 \%$ of the data on either end). 
begins to increase. ${ }^{12} 13$ At the median unemployment rate for the sample (5.6 percent), the marginal effect of a one percentage point increase in the unemployment rate is a drop in time

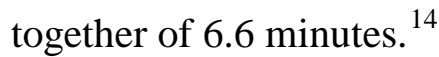

Next, we estimate the quadratic model for various subsamples. Not only do these estimates provide further robustness checks, but they also highlight whether different subsamples of the population who were more (or less) likely to lose their job as a result of the Great Recession saw larger impacts of state unemployment rates on time together. ${ }^{15}$ In row (B) of Table 1, we explore whether the effect of the business cycle on time together varies by race/ethnicity. We see that the relationship is statistically significant for non-Hispanic whites and for those of Hispanic origin. Although the coefficient estimates for non-Hispanic blacks are similar to those of non-Hispanic whites, they are imprecise due to the smaller sample size. Because non-Hispanic blacks experienced much higher unemployment rates during the Great Recession, this result suggests that the pattern of time together over the business cycle is not

\footnotetext{
${ }^{12}$ We also estimated a specification using unemployment rate bin indicators (see Appendix A5). Compared to a rate of 4-6 percent, married couples spent less time together at 8-10 percent, though the result is of marginal significance.

${ }^{13}$ This analysis focuses on married couples with co-resident children under age 19. In results not shown, when we expand the sample to include all couples, we find similar results. However, when considering only the sample of couples without household children, we find a positive linear effect whereby a one percentage point increase in the unemployment rate is associated with a 4.9 minute increase in couples' time together. We chose to focus on married couples with children to better capture the trade-off between synchronizing schedules for shared leisure and staggering schedules to share in childcare.

${ }^{14}$ If we include a linear or quadratic time trend instead of year fixed effects, we still find a U-shaped relationship; however, the relationship is less pronounced. If we include a state-specific time trend, we also find a similar relationship.

${ }^{15}$ Elbsy et al. (2010) and Hoynes et al. (2012) document that males were more affected than females, those who do not hold a college degree were more affected than those with a college degree, youths were more affected than prime-age workers and the elderly, and blacks and Hispanics were more affected than non-Hispanic whites and Asians. Most of these differences were due to job losses in industries such as construction and manufacturing.
} 
concentrated solely amongst those who experience a job loss directly or whose labor market experiences are most affected by business cycles.

In the next three sets of rows, we examine the effects for dual-earner couples, by the pay status of dual-earner couples, and by the father's education level. These will provide further evidence of whether groups with the highest unemployment rates also see larger changes in time use over the business cycle. In addition, these results explore whether families where one or more spouse is at a higher risk for working outside of normal business hours at temporary or part-time work are more affected. Employment status is defined as one throughout the paper if the parent has a job for pay or profit at the time of the ATUS interview, and as zero otherwise. We define dual-earner status here as whether each member of the couple reported that they were employed in the last seven days for pay or profit at the time of the ATUS interview. ${ }^{16}$ Although the standard errors increase when the sample is divided, in row (C) of Table 1 we see that the estimated coefficients for dual-earner couples are quite similar to those for the entire couple sample. If the sample composition is not changing dramatically over time, this suggests that our results are not being driven by job loss. However, we caution the reader that results should be considered descriptive rather than causal here, because employment status is potentially endogenous.

Next we consider the pay status of the couple among dual-earner couples as an indicator for the quality of job. For this exercise, we use the pay status of the respondent from the ATUS, but the pay status of the respondent's spouse from the CPS (the spouse must be employed to

\footnotetext{
${ }^{16} 110$ married mothers and 42 married fathers do not report being employed but reported minutes of work on their diary day. We use the employed definition for official BLS labor force statistics (TELFS=1 or 2). Some respondents may have done unpaid work in a family business.
} 
report pay status). ${ }^{17}$ Our dual-earner-couple sample in row (D) is smaller than in row (C) because the CPS inquires about pay status only from wage and salary workers. In addition, 14 percent of the sample is missing pay status among those who were asked for their status. In row (D) of Table 1, we observe that the U-shaped pattern still holds for couples where both spouses are salaried workers. When the mother works hourly, the magnitude of the effect is even stronger. This suggests that the effects of high unemployment on time together are concentrated among families where the mother is an hourly worker and therefore may be more likely to be working at non-standard hours. In Section V, we explore whether the probability of men or women working non-standard hours changes over the business cycle. Surprisingly, when the father is paid hourly and the mother is paid a salary, we find an inverted U-shaped pattern with a maximum time together at unemployment rates around 10 percent. This is the only inverted Ushaped relationship we find for couple time together and the unemployment rate, and it may be due to a change in the sample composition over the business cycle.

We next consider separately the sample of couples where the husband has a college degree or not in row $(\mathrm{E})$ of Table $1 .^{18}$ Although the average time spent with spouse is very similar between the groups, the estimated effect of the unemployment rate is much larger for couples where the husband has not earned a college degree. As pointed out in Colman and Dave (2011), men without a college degree are disproportionately affected by high unemployment.

\footnotetext{
${ }^{17}$ The CPS asks respondents about the easiest way to report earnings. If they report "hourly", they are classified as paid hourly. If they give some other periodicity, they are asked whether they are paid hourly. Presumably, most non-hourly workers are paid a salary, although they could be paid commissions or piece rate. In the ATUS, data is also collected on hourly pay status for the respondent only. Thus, the spouse's pay status is available only in the CPS, which is reported two to five months before the ATUS interview.

${ }^{18}$ The sample by husband's college degree status does not sum to the total couple sample because education is missing for some respondents and their spouses.
} 
Similarly, to the extent that college education is a proxy for the socioeconomic status of the couple, the families where the father does not have a college degree might be more affected by depressed wages during periods of higher unemployment levels.

We next consider whether the relationship between the unemployment rate and time together is different before or after the beginning of the financial crisis with the collapse of Lehman Brothers in September of 2008. The average unemployment rate is 5.23 before the crisis and 7.46 after the crisis began. On average, couples spent 11 fewer minutes together prior to the financial crisis. In row (F) of Table 1, we see that the relationship between the unemployment rate and family time together is very similar in both time periods and is still Ushaped. We do not distinguish between the official Great Recession dating period (December 2007-June 2009) and the recovery in GDP in late 2009 because the unemployment rate and household mortgage foreclosure rates have remained at historical highs.

Row (G) of Table 1 considers separately time diaries from the summer months (June through August). Because our sample includes only couples with children under age 19, it may be that childcare concerns are greatest during the summer months when school is not in session. Interestingly, we find that couples with children are spending 10 minutes more together per day on average during the summer months. Both the summer and school-year diaries show the same U-shaped pattern of couples' time together. During the summer months, we see a much sharper decline in time spent together as the unemployment rate rises, but for both groups the lowest point of time together is when the unemployment rate is approximately 9 percent.

We next examine time on weekdays separately from time on weekends. Estimated coefficients are reported in row $(\mathrm{H})$ of Table 1 . Note that, on average, couples spend more than twice as much time together on a weekend day than on a weekday (398 minutes versus 186 
minutes). We find that the U-shaped relationship occurs for both weekdays and weekend days, but there is a larger decline in time spent together on weekend days as the unemployment rate rises. Finally, we consider time that parents spend together in the presence of their children, "family time”, and alone as a couple. Coefficient estimates are almost identical.

On the whole, the results in Table 1 and Figure 2 indicate that couples' time together does vary over the business cycle with a U-shaped pattern. Although we are limited by small sample sizes, we do find evidence that the effects are stronger among couples where the wife is an hourly worker in dual-earner couples and where the husband does not have a college degree. Not only are these couples more likely to experience a job loss during periods of high unemployment, but they also may be more likely to work during non-standard hours. It may be that these couples adjust their time working to trade off childcare duties, resulting in less time spent together as a couple. We explore whether couples adjust their working schedules over the business cycle in Section V.

We next consider how time spent with children varies with the state-level unemployment rate. We begin by again graphing the weighted means by grouping observations together into bins of state-level unemployment rates. Figure 3 presents the average time each parent spends with any of their children, presented separately for fathers and mothers. We see that for mothers, time spent with children is basically flat, with only a dip down when the state unemployment rate is between 8 and 10 percent. The dip in average time spent with children is statistically significant (343.90 minutes for the 8-10 percent unemployment group relative to 361.42 minutes for the 4-6 percent unemployment group). This is consistent with a peak in both the probability of being employed and minutes worked for those experiencing 8-10 percent unemployment 
rates, shown later in Figure 4. For fathers in Figure 3, we see that, if anything, time with children is increasing as the state unemployment rates increase.

We explore these raw patterns further in regression analysis. In Panel 1 of Table 2, we find that for mothers, total time with children does not vary with the state unemployment rate. We also consider time spent engaging in enriching activities and enriching activities alone with children, but again find no significant relationship between these activities and the unemployment rate. Similarly, for fathers, presented in Panel 2 of Table 2, total time with children is not significantly related to the state unemployment rate. However, the estimated coefficient for enriching time alone with children is positive and linear. The specification presented in Table 2, Panel 2, column (5), indicates that as the unemployment rate rises by one percentage point, fathers spend an additional one minute per day in enriching time alone with children. Given that fathers spend only 19 minutes per day on average alone with their children in enriching activities, an increase of one minute per day is approximately a 5 percent increase.

In Table 3, Panel 1, we further examine which activities fathers spend more time in as the economy worsens. We find that they spend more time in non-sport play activities and sport activities. In Table 3, Panel 2, we explore which enriching activities fathers are spending more time engaging in alone with their children — where they are more likely to be actively involved in the activity. We find an inverted U-shaped relationship with reading and homework. The point estimates suggest that at the median unemployment rate of 5.6 percent, a one percentage point increase in the unemployment rate is associated with an additional 29 seconds reading and doing homework with children (about a 14 percent increase relative to the mean of 3.29 minutes). The time fathers spend alone with children begins to drop once the unemployment rate exceeds 8.3 percent. The estimated coefficient in Table 3, column (5) suggests that as the 
unemployment rate rises by one percentage points, fathers spend an additional 40 seconds participating in sports with their children, relative to a mean of 3.85 minutes (about 18 percent more time). The fact that we observe a change in enriching time but not total time with children suggests that fathers are choosing enriching activities over non-enriching activities as the unemployment rate rises, which may be beneficial for child well-being.

In Table 4, we explore how the time fathers spend in childcare activities over the business cycle differs by dual-earner status of the couple and father's education level. The specification in Table 4, Panel 1 is the same as in Table 2, Panel 2, Columns (1) and (2), where we found no significant relationship between the total time fathers spend with children and the state unemployment rate. Like Guryan et al. (2008), our means indicate that highly-educated fathers spend significantly more time with their children than less-educated fathers (253 versus 236 minutes). They interpret this as an indication that those with a higher opportunity cost of time (the higher-earning highly-educated fathers) have a stronger preference for spending time with children. We might therefore expect that as work hours temporarily fall during periods of high unemployment, highly-educated fathers would allocate more time to their children relative to those with less education. However, we see no strong pattern in Table 4, Panel 1, with the exception that for fathers without a college degree there is a slight U-shaped relationship.

The specification in Table 4, Panel 2 is the same as in Table 2, Panel 2, Columns (5) and (6), where we found that fathers increase enriching time alone with children as the unemployment rate rises. In Table 4, Panel 2, we find that father's enriching time alone with children varies in a strong inverted U-shaped pattern with the unemployment rate for dual-earner couples. This suggests that it is not simply the time windfall associated with job loss that results in fathers spending more time engaging their children in enriching childcare activities. Among 
dual-earner couples, fathers spend the most time with their children alone at an unemployment rate of 10.6 percent. We see only a positive linear relationship for fathers without a college degree, but for fathers with a college degree we again find an inverted U-shaped relationship, with a peak at an unemployment rate of 9 percent. The difference between fathers with and without a college degree suggests these groups of men react differently at the highest levels of unemployment, with less-educated fathers still increasing enriching time with children while more-educated fathers cut back on this time. The families where the father has less than a college degree are more likely to be directly affected by a bad economy. Alternatively, these results may be a function of the wife's time constraints and labor market experiences.

\section{Time and Timing of Work}

In order to better interpret our main results on family time together over the business cycle as presented in section IV, we next consider how the total amount of time spent at work and how the timing of work hours varies over the business cycle. These results will shed light on whether and how the patterns of family time together are due to changes in time spent working. When individuals experience a job loss, they may use that time windfall on leisure activities, and thus may spend more time with their spouse and/or children (Burda and Hamermesh 2010). However, the time a family spends together may also be related to their work schedules, not just the overall amount of time working (Connelly and Kimmel 2011).

Our findings in Section IV suggest an important difference in thinking about family time together over the business cycle. Couples with co-resident children under age 19 spend less time together as the unemployment rate rises, but this relationship is U-shaped, with couples spending more time together when local unemployment rates are at their highest. This suggests that couples are best able to synchronize their work schedules during periods of very high and very 
low unemployment. The former may, unfortunately, be due to less than desired overall time spent working during periods of very high unemployment. Meanwhile, we also find that fathers spend more time alone with children in enriching childcare activities as the unemployment rate rises, and for fathers with a college degree this relationship has an inverted U-shape. One interpretation is that at lower levels of unemployment, couples find time for each other but the opportunity cost of fathers' time is at its highest and fathers spend less time in enriching activities with children, which have market substitutes.

Previous research using cross-sectional data finds that among married parents when one partner is observed working nonstandard hours, it is common that the parents have staggered work hours so that each is working a different shift. This results in parents spending less time with their spouse; however, fathers spend more time in childcare activities and time alone with children, which may be developmentally important (Wright et al., 2008; Polivka, 2008). In addition, Connelly and Kimmel (2011) show that mothers and fathers who work the majority of their hours outside of 8 a.m. -4 p.m. engage in childcare throughout the day, while mothers and fathers who work the majority of their hours during the "standard" 8 a.m. -4 p.m. time slot spend more time in childcare in the mornings and early evenings.

We therefore look for evidence of a change in the probability of working outside the traditional weekday hours over the business cycle. We expect that working during non-standard hours decreases the time couples spend together but increases time that a spouse spends in childcare activities. For our results reported in Section III to be consistent with non-standard work hours, we would see women working more non-standard hours when the unemployment rate is approximately 8 to 9 percent; because during those periods, couples' time together is at its minimum but fathers are spending more time in enriching childcare activities. 
We consider a parent's probability of being employed overall and the number of minutes worked on the diary day if employed. Minutes of work includes all time working at a main job and other jobs, work-related activities, and other income-generating activities, but excludes job search activities. Figure 4 presents the percent employed and the average minutes per day working conditional on being employed by state unemployment rate bins. Note that in this figure we combine the weekday and weekend day diaries. In Figure 5 and in the regression analysis discussed below, we examine work time on weekdays and weekend days separately.

In Figure 4A, we see that for both mothers and fathers the probability of working drops when the unemployment rate is 10 percent or more. For both samples, the percent working when the unemployment rate is 10 percent or higher is statistically significantly lower than the mean probability of working when the unemployment rate is between 4 and 6 percent. In Figure 4B, we consider the average minutes working per day conditional upon working. For fathers, we do see a U-shaped pattern of average minutes working per day conditional upon being employed, where fathers are working the most minutes during periods of very high and very low unemployment. We also see a slight bump up in minutes of work for mothers when the unemployment rate is between 8 and 10 percent, but this is not statistically significantly different than the mean at an unemployment rate between 4 and 6 percent. On average, parental time working does not exhibit a strong cyclical pattern even though the average workweek for all employees on private nonagricultural payrolls fell by 54 minutes during the current recession (Kroll 2011).

Figures $5 \mathrm{~A}$ and $5 \mathrm{~B}$ explore the timing of work for mothers and fathers, respectively. We define a parent as working in a time slot if he/she worked at least 60 minutes in a workplace during the interval. Because work done at home may be combined with childcare, we did not 
include that in our definition (Eldridge and Pabilonia 2010). Given that there is only one diary day per individual, we cannot assess whether work in these intervals is typical (i.e., working in a job with non-standard hours) or is an anomaly (i.e., having to work overtime). Still, these results allow us to measure whether, on average, timing of work hours varies by the state unemployment rate. Here, the time intervals are for weekdays only, with any time on weekends plotted separately.

In Figure 5A, a few interesting patterns emerge. First, for women, there appears to be a bump up in working during any time slot when the unemployment rate is between 8 and 10 percent. Also for women, there is a fall in time spent working during standard hours of 8 a.m. 2 p.m. and 2 p.m. -6 p.m., when the unemployment rate is 10 percent plus, while working during standard hours is most common when the state unemployment rate is below 4 percent. In Figure 5B, for fathers, time spent working during standard work hours falls as the unemployment rate rises.

In Table 5, we first consider work patterns for mothers and fathers by estimating a version of equation (1) where we instead look at time spent working as the dependent variable. ${ }^{19}$ We model the unemployment rate in "bins" to highlight the non-linear relationship. ${ }^{20}$ For mothers, in column (2) of Panel 1 in Table 5, we see that the average minutes worked among those currently working drops sharply by about 36 minutes when the unemployment rate exceeds 10 percent. Although not statistically significant when the sample is divided between weekend day and weekday diaries, we see that in both samples the estimated coefficient on minutes

\footnotetext{
${ }^{19}$ All models are estimated using ordinary least squares, so the estimates in Tables 5, columns (1) and (3)-(8), are marginal effects from linear probability models. Estimating these regressions with logit models yields similar results.

${ }^{20}$ Note that the highest state unemployment rate in the data is 14.86 , so the top bin actually spans more than 4 percentage points.
} 
worked conditional upon working on the diary day is negative (columns 3 and 10). This suggests that the effect is not occurring solely on weekdays.

Next, we look for evidence of an increase in work at non-standard hours. Columns (3) to (8) consider weekday diaries. Recall that in Table 1, couples’ time together fell more dramatically on weekend days than weekdays as the economy worsened. This may be because the majority of work is done on weekdays and children's school/daycare schedules provide an additional constraint on the ability to synchronize schedules. In Columns (9) and (10), we estimate the models for weekend day diaries, where we might see parents taking on weekend shifts to supplement the family income during periods of high unemployment.

In Table 5, Panel 1, columns (5) and (6), we see that at the highest unemployment levels, women are significantly less likely to be working during the standard work hours of 8 a.m. -2 p.m. and 2 p.m. -6 p.m. In column (9), we see that women are more likely to work on weekends when the unemployment rate is 8 percent or more relative to the baseline unemployment rate of between 4 and 6 percent. Therefore, we conclude that mothers are working more nonstandard hours during times when the unemployment rate is 8 percentage points plus. This is consistent with couples spending less time together but fathers spending more time in enriching childcare activities. Note that these results are contrary to the findings in Connelly and Kimmel (2011). Over the 2003-2006 period, they found that mothers living in states with high unemployment rates were less likely to work non-standard schedules; however, only a few respondents lived in a state where unemployment rates was 8 percent plus in this period.

In Panel 2 of Table 5, we see that fathers are working significantly more hours on weekend days as the unemployment rate rises above the baseline rate of 4-6 percent. We find that men are working 43 minutes more when the unemployment rate is between 6 and 8 percent, 
which is an increase of about 13 percent of the mean of 328 minutes. When the unemployment rate is 10 percent plus, they are working 72 minutes more than at baseline rates. We also find that they are more likely to be working before 8 in the morning at rates of $8-10$ percent compared to rates of 4-6 percent. These results are consistent with couples spending less time together on weekend days during periods of high unemployment. ${ }^{21}$

\section{Discussion and Conclusion}

This paper examined how families' time together during the period 2003-2010 is associated with changes in local economic conditions, as approximated by state-level unemployment rates. We find that the time that couples spend together exhibits a U-shaped pattern with respect to the unemployment rate, with the highest amount of couple time together at very low and very high levels of unemployment. Thus, during the Great Recession when state unemployment rates exceeded 10 percent, couples did spend more time together. These results hold even for dual-earner couples, suggesting that the pattern is not being driven by individual job losses. However, the results are concentrated among families where the wife is hourly versus salaried and where the husband has no college degree, suggesting that those most affected by the recession see the biggest changes in time together over the business cycle.

We also examined the time that parents spend with all their household children under age 19. We find that as the economy worsens, fathers spend additional time alone with their children in enriching childcare activities, such as reading, homework, and sports, which could affect longrun child outcomes. We consider how the time spent working and the timing of work varies over the business cycle. For women, we find no evidence of a change in the probability of being

\footnotetext{
${ }^{21}$ Results for specifications in Table 5 for the sample of dual-earner couples are similar, but less precise (estimates available upon request).
} 
employed due to relatively high unemployment rates but a significant decrease in the total minutes spent working among the employed. Thus, we do not find evidence of women acting as "added workers" and working more when unemployment rates are high. However, we do see women shifting from standard weekday working hours to weekend days when unemployment rates are highest. Although men are not more likely to work on weekends, among those working on weekends, they are working significantly more hours when the unemployment rate is high.

An increase in women working during nonstandard hours could explain the decrease in the time couples spend together, which had its lowest point at unemployment rates between 8 and 9 percent. At the same, it may also explain the increase in time that the fathers are spending alone with children in enriching childcare activities. Previous literature has found that it is not only the total amount of time working but also when individuals are able to schedule their work that affects investments in children and couples' time together. We show that the way family time together is affected by state unemployment rates is consistent with observed patterns of time spent working.

Macroeconomic conditions affect family time together. We find effects not just for those who lose their jobs, but also for couples where both partners continue to work. The fact that the state unemployment rate clearly affects individuals who do not lose their job also implies that the unemployment rate is an invalid instrument for an individual's employment status, as it so frequently is used in the economics literature. 


\section{References}

Aguiar, Mark, and Erik Hurst. 2007. "Measuring Trends in Leisure: The Allocation of Time over Five Decades." Quarterly Journal of Economics 122, no. 3: 969-1006.

Aguiar, Mark, Erik Hurst, and Loukas Karabarbounis. 2011a. “The New Economics of Time” Prepared for the Annual Review of Economics, August 2011.

Aguiar, Mark, Erik Hurst, and Loukas Karabarbounis. 2011b. “Time Use During Recessions.” NBER Working Paper 17259.

Amato, Paul R., and Brett Beattie. 2011. "Does the Unemployment Rate Affect the Divorce Rate? An Analysis of State Data 1960-2005," Social Science Research, forthcoming.

Arkes, Jeremy, and Jacob Alex Klerman. 2009. "Understanding the Link between the Economy and Teenage Sexual Behavior and Fertility Outcomes." Journal of Population Economics 22, no. 3: 517-536.

Bianchi, S.M., J.P. Robinson and M.A. Milkie. 2006. Changing Rhythms of American Family Life. New York: Russell Sage.

Burda, Michael C., and Daniel S. Hamermesh. 2010. "Unemployment, Market Work and Household Production." Economics Letters 107, no. 2: 131-133.

Colman, Gregory, and Dhaval Dave. 2011. "Exercise, Physical Activity, and Exertion over the Business Cycle.” Working Paper, October.

Connelly, Rachel and Jean Kimmel. 2009. “Spousal Influences of Parents’ Non-Market Time Choices.” Review of Economics of the Household 7: 361-394.

Connelly, Rachel and Jean Kimmel. 2011. “The Role of Non-standard Work Status in Parental Caregiving for Young Children.” Eastern Economic Journal 37: 248-269.

Eldridge, Lucy, and Sabrina Wulff Pabilonia. 2010. “Bringing Work Home: Implications for BLS Productivity Measures.” Monthly Labor Review 133, no. 12, 18-35.

Elsby, Michael, Bart Hobijn, and Ayşegül Şahin. 2010. “The Labor Market in the Great Recession.” Prepared for Brookings Panel on Economic Activity, March 18-19, 2010. 
Evans, William N. and Timothy J. Moore. 2011. "Liquidity, Economic Activity, and Mortality.” Review of Economics and Statistics, forthcoming.

Folbre, Nancy, Jayoung Yoon, Kade Finnoff, and Allison Sidle Fuligni. 2005. "By What Measure? Family Time Devoted to Children in the United States.” Demography 42, no. 2, 373-90.

Gimenez-Nadal, José Ignacio, José Alberto Molina, and Raquel Ortega. 2010. “Unemployment and Time Use: Evidence from the Spanish Time Use Survey.” Working Paper. University of Zaragoza, February 2010.

Guryan, Jonathan, Erik Hurst, and Melissa Kearney. 2008. "Parental Education and Parental Time with Children.” Journal of Economic Perspectives 22, no. 3, 23-46.

Halberg, Daniel. 2003. "Synchronous Leisure, Jointness, and Household Labor Supply,” Labour Economics 10, 185-202.

Hamermesh, Daniel S. 2002. "Timing, Togetherness and Time Windfalls." Journal of Population Economics 15, no. 4: 601-623.

Hellerstein, Judith K., and Melinda S. Morrill. 2011. "Booms, Busts, and Divorce.” The B.E. Journal of Economic Analysis \& Policy 11, Iss. 1 (Contributions), Article 54.

Hoynes, Hilary W., Douglas L. Miller, and Jessamyn Schaller. 2012. "Who Suffers During Recessions?” Journal of Economic Perspectives, forthcoming.

Jenkins, S., \& L. Osberg. 2005. "Nobody to play with? The Implications of Leisure Coordination” in D. Hamermesh \& G. Pfann (eds.), The Economics of Time Use (pp. 113-145). Amsterdam: Elsevier.

Juster, F. Thomas. 1985. “The Validity and Quality of Time Use Estimates Obtained from Recall Diaries.” in F. Thomas Juster and Frank P. Stafford (eds.) Time, Goods, and WellBeing. Survey Research Center, Institute for Social Research, University of Michigan: Ann Arbor, Michigan: 63-91.

Kroll, Steve. 2011. “The Decline in Work Hours During the 2007-09 Recession.” Monthly Labor Review 134, no. 4: 53-59. 
Krueger, Alan B., and Andreas Mueller. 2010. “Job Search and Unemployment Insurance: New Evidence from Time Use Data.” Journal of Public Economics 94, no. 3-4, 298-307.

Krueger, Alan B., and Andreas Mueller. 2012. “Time Use, Emotional Well-Being and Unemployment: Evidence from Longitudinal Data.”American Economic Review (Papers and Proceedings), forthcoming.

Lundberg, Shelly, Sabrina Wulff Pabilonia, and Jennifer Ward-Batts. 2008. "Time Allocation of Parents and Investments in Sons and Daughters.” Working paper.

Morgan, S. Phillip, Diane N. Lye, and Gretchen A. Condran. 1988. “Sons, Daughters and the Risk of Marital Disruption.” American Journal of Sociology 94, no. 1, 110-29.

Pabilonia, Sabrina Wulff. 2001. “Evidence on Youth Employment, Earnings, and Parental Transfers in the National Longitudinal Survey of Youth 1997.” Journal of Human Resources 36, no. 4: 795-822.

Pabilonia, Sabrina Wulff and Younghwan Song. 2011. "Single Mothers' Time Preference, Smoking, and Enriching Childcare: Evidence from Time Diaries." Eastern Economic Journal, forthcoming.

Pailhe, Ariane, and Anne Solaz. 2008. “Time with Children: Do Fathers and Mothers Replace Each Other When One Parent is Unemployed?” European Journal of Population, 24: 211-236.

Polivka, Anne. 2008. "Day, Evening and Night Workers: A Comparison of What They Do in their Nonwork Hours and with Whom They Interact.” In How Do We Spend Our Time?: Evidence from the American Time Use Study, ed. Jean Kimmel, Kalamazoo, MI: W.E. Upjohn Institute for Employment Research.

Ruhm, Christopher J. 2000. “Are Recessions Good for Your Health?” The Quarterly Journal of Economics 115, no. 2: 617-650.

Şahin, Ayşegul, Joseph Song, and Bart Hobijn. 2010. “The Unemployment Gender Gap During the 2007 Recession.” Current Issues in Economics and Finance Federal Reserve Bank of New York 16(2).

Schaller, Jessamyn. 2012. "For Better if Not For Worse: Marriage and Divorce over the Business Cycle.” Journal of Population Economics, forthcoming. 
Stewart, Jay. 2010. "The Timing of Maternal Work and Time with Children." Industrial and Labor Relations Review 64, no. 1: 181-201.

Tapia Granados, José A. 2005. "Increasing Mortality during the Expansions of the US Economy, 1900-1996." International Journal of Epidemiology 34, no. 6: 1194-1202.

U.S. Department of Labor, U.S. Bureau of Labor Statistics. 2011. “American Time Use Survey User’s Guide.”

Wright, Vanessa R., Sara B. Raley, and Suzanne M. Bianchi. 2008. “Time for Children, Spouse, and Self Among Parents Who Work Nonstandard Hours.” Social Forces 87, no. 1, 243271. 


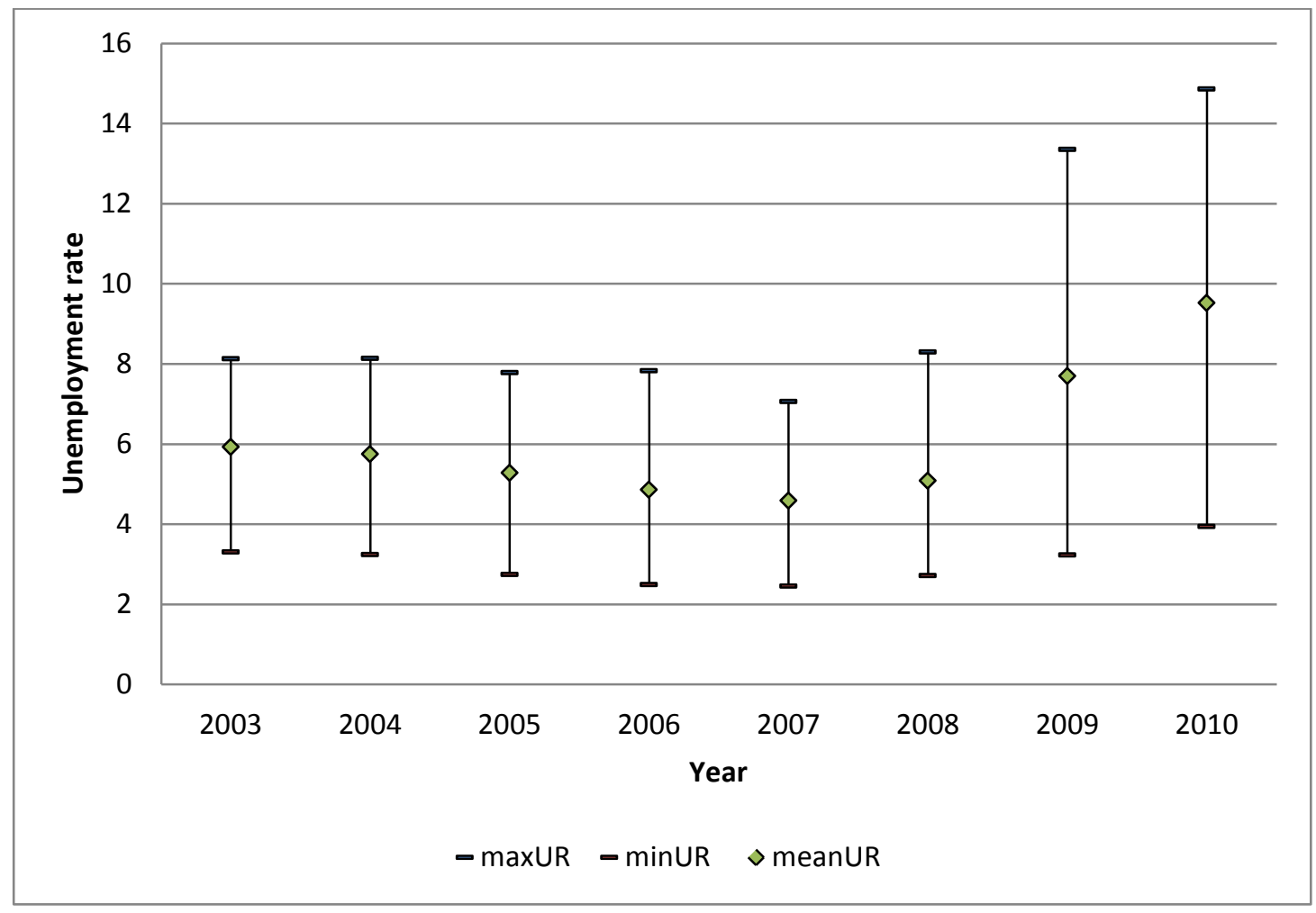

Figure 1: Mean and Range of State Unemployment Rates, 2003-2010 


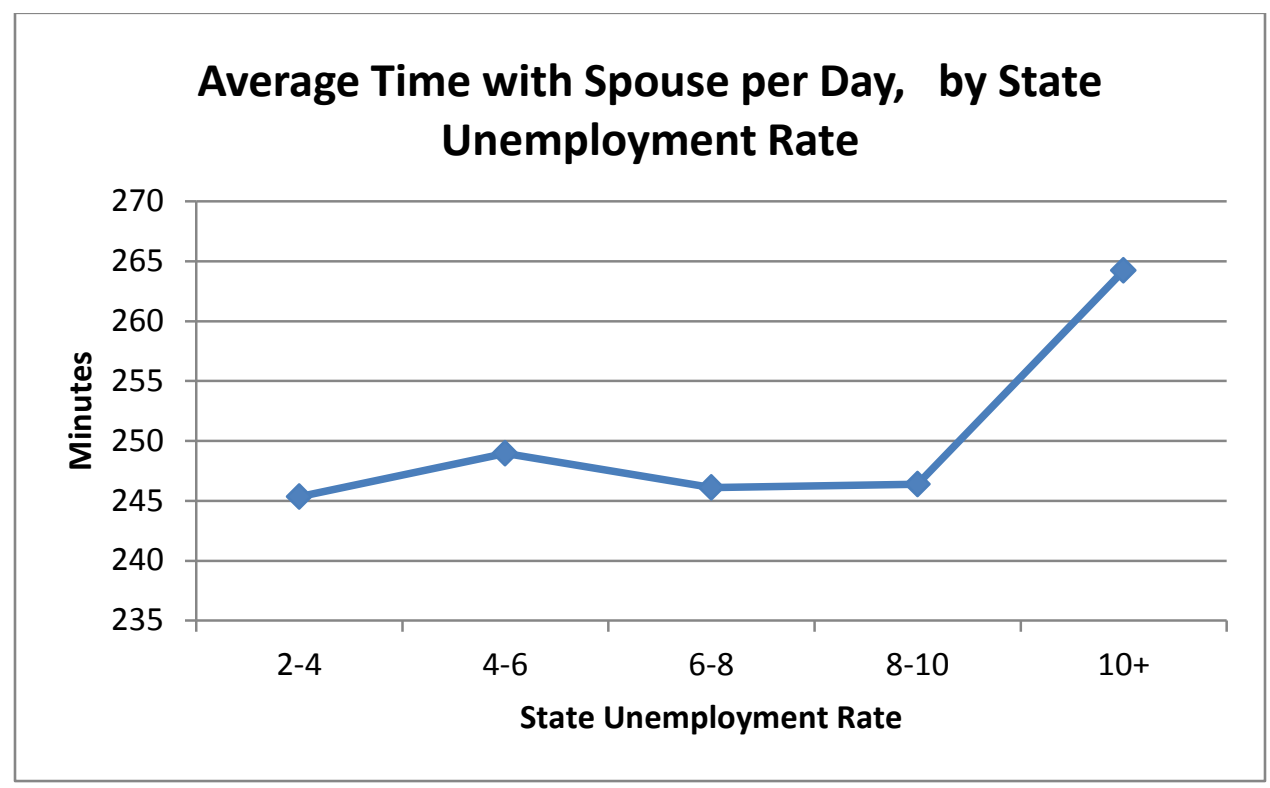

Figure 2: Couple time together by State Unemployment Rate 


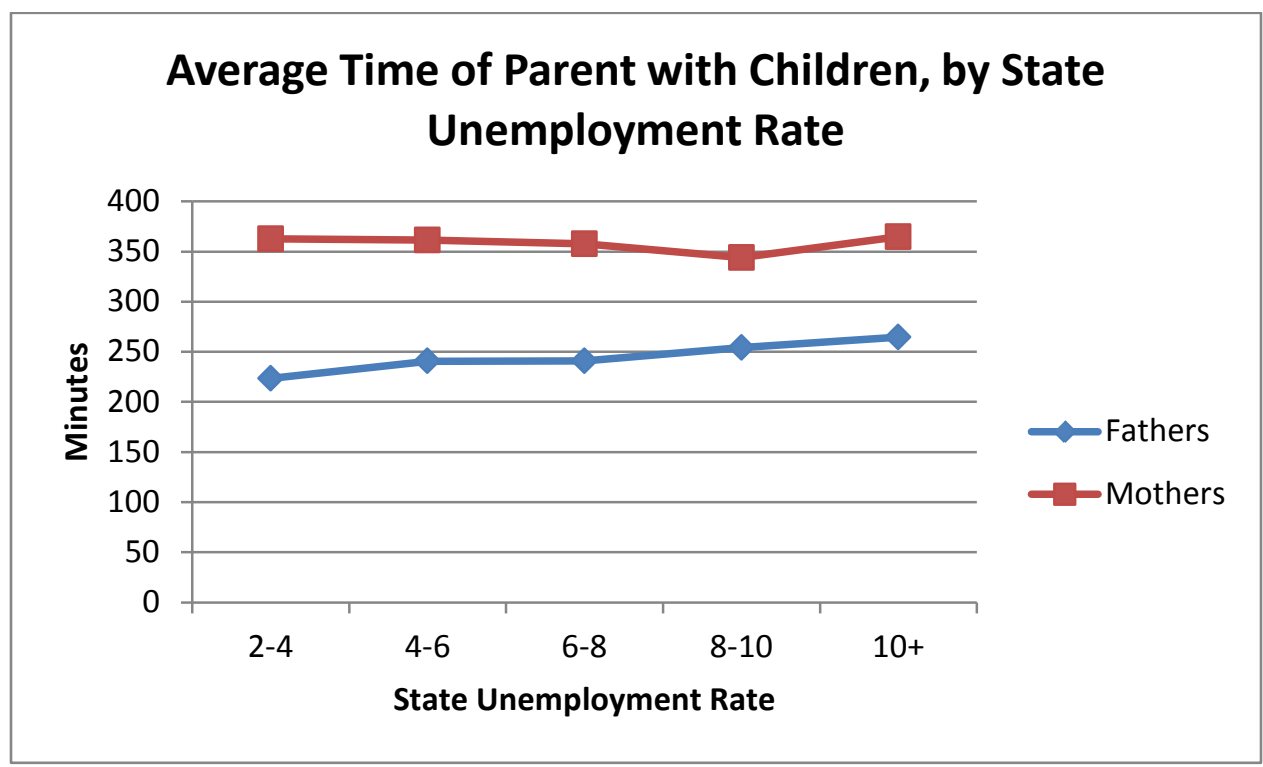

Figure 3: Parents time with children by state unemployment rate (in minutes) 


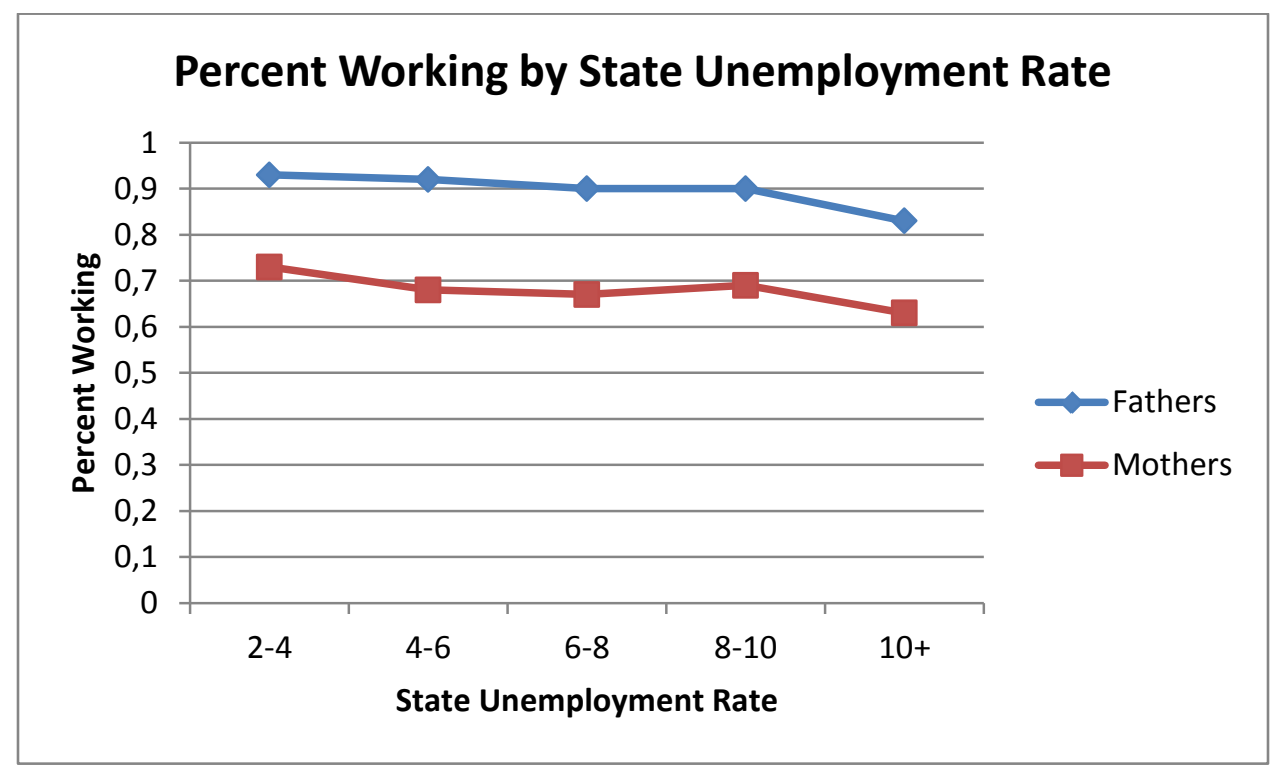

Figure 4A: Time spent working 


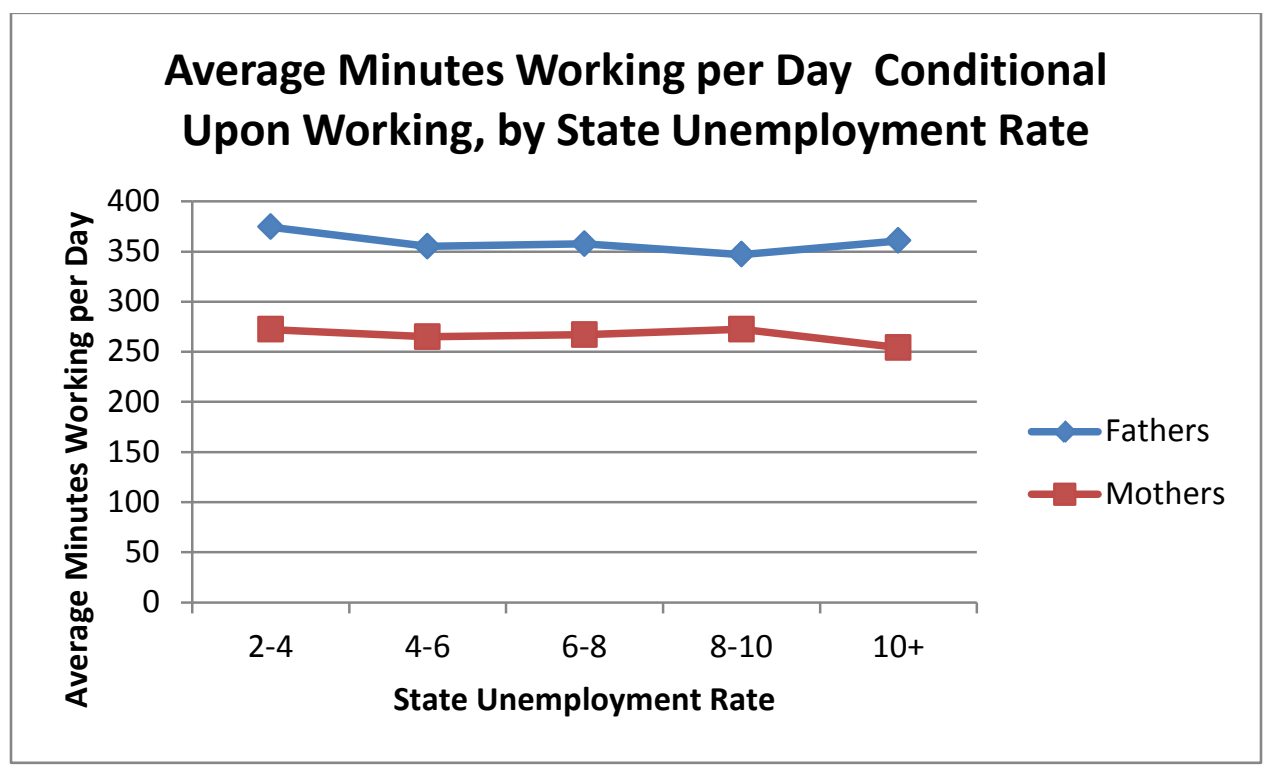

Figure 4B: Time spent working 


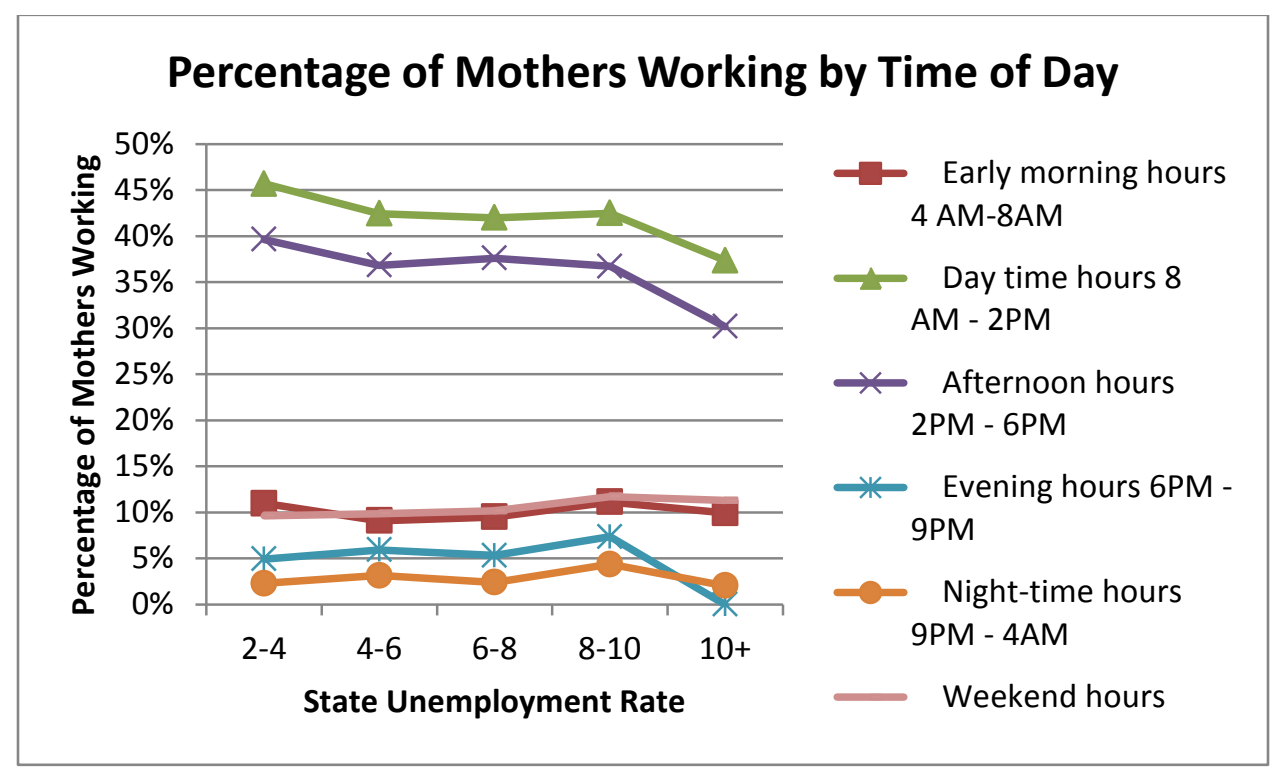

Figure 5A: Time spent working at each point on the day (Parent must have worked at least 60 minutes in a workplace to be included in each interval). 


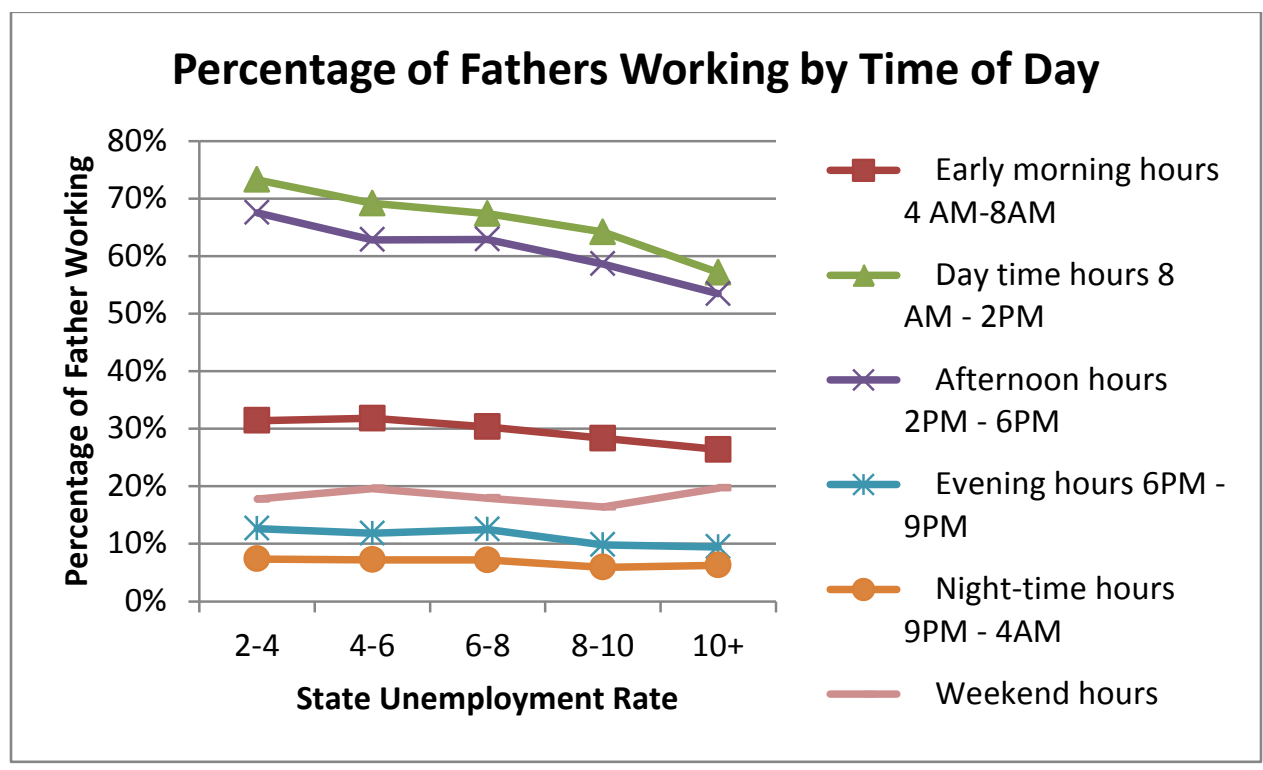

Figure 5B: Time spent working at each point on the day (Parent must have worked at least 60 minutes in a workplace to be included in each interval). 
Table 1. Parents' Time Together

Dependent Variable: All Time with Spouse (in minutes)

\begin{tabular}{|c|c|c|c|c|c|c|c|}
\hline & Sample & & $\mathbf{N}$ & $\begin{array}{l}\text { Mean Dep. Var. } \\
\text { (SD) }\end{array}$ & Urate & Urate $^{2}$ & $\mathbf{R}^{2}$ \\
\hline \multirow[t]{2}{*}{ (A) } & \multirow[t]{2}{*}{ Full Sample } & & \multirow[t]{2}{*}{34,001} & \multirow[t]{2}{*}{$248.81(247.64)$} & $-0.702(2.152)$ & & 0.017 \\
\hline & & & & & $-18.355 * * *(6.090)$ & $1.050 * * *(0.378)$ & 0.017 \\
\hline \multirow[t]{3}{*}{ (B) } & \multirow[t]{3}{*}{ Race/Ethnicity } & Non-Hispanic Whites & 25,252 & $250.59(258.53)$ & $-17.859 * * *(5.798)$ & $0.942 * *(0.360)$ & 0.016 \\
\hline & & Non-Hispanic Blacks & 1,918 & 204.77(230.03) & $-20.453(23.148)$ & $1.160(1.267)$ & 0.051 \\
\hline & & Hispanic & 4,748 & 261.17(229.38) & $-33.997(20.898)$ & $2.327 * *(1.074)$ & 0.031 \\
\hline (C) & Earner Status & Dual-Earner Couple & 21,114 & $229.30(242.93)$ & $-13.704 *(7.744)$ & $0.847 *(0.435)$ & 0.021 \\
\hline \multirow[t]{4}{*}{ (D) } & \multirow{4}{*}{ Dual-Earner’s Pay Status } & Both Salaried & 5,051 & 239.24(225.27) & $-24.316 *(12.217)$ & $1.643 * *(0.677)$ & 0.029 \\
\hline & & Father Salaried & 1,915 & 223.63(230.43) & $-28.673(20.674)$ & $2.231 *(1.279)$ & 0.078 \\
\hline & & Mother Salaried & 945 & 234.22(224.59) & $69.258 * *(30.821)$ & $-3.446 *(1.886)$ & 0.109 \\
\hline & & Both Hourly & 5,065 & 220.19 (223.89) & $-31.848 * *(13.648)$ & $1.693 * *(0.713)$ & 0.033 \\
\hline \multirow[t]{2}{*}{$(\mathrm{E})$} & \multirow[t]{2}{*}{ Father’s Degree } & College & 13,628 & $251.62(245.26)$ & $-4.111(9.424)$ & $0.259(0.579)$ & 0.025 \\
\hline & & No College & 20,204 & 247.58(229.44) & $-25.159 * * *(7.724)$ & $1.447 * * *(0.424)$ & 0.019 \\
\hline
\end{tabular}

Notes: Sample includes only couples with co-resident children under age 19. Spouse's pay status in row D is determined at the time of the CPS interview. The dependent variable is any time with spouse except for in row I where the dependent variable is time with spouse but not children present. Unemployment rates are measured at the state-level and all specifications include state and year fixed effects. ATUS final weights used. Standard errors adjusted for clustering by state are reported in parentheses. ***significant at $1 \%$; **significant at 5\%; *significant at 10\%. Control variables include own and spouse's age and age squared, and indicators for husband and wife education (high school dropout, some college, college, missing), race and ethnicity (non-Hispanic black, other, Hispanic), gender, age of youngest household child (infant, preschooler, elementary), household child older than age 18, lives with other adults, cohabitating couple, gender composition of the children (all boy, mixed gender), season, and respondent lives in SMSA. 
Table 1. Parents' Time Together (Continued)

Dependent Variable: All Time with Spouse (in minutes)

\begin{tabular}{|c|c|c|c|c|c|c|c|}
\hline & Sample & & $\mathbf{N}$ & $\begin{array}{l}\text { Mean Dep. Var. } \\
\text { (SD) }\end{array}$ & Urate & Urate $^{2}$ & $\mathbf{R}^{2}$ \\
\hline$(F)$ & & Sep 2008-Dec 2010 & 9,153 & 256.34(266.74) & $-21.304 * *(10.421)$ & $1.075 *(0.553)$ & 0.027 \\
\hline (G) & & Summer & 8,358 & $256.45(248.85)$ & $-36.911 * * *(12.954)$ & $2.038 * * *(0.760)$ & 0.022 \\
\hline \multirow[t]{2}{*}{$(\mathrm{H})$} & Day of Week & Weekdays & 16,465 & 185.62 (203.58) & $-16.298 * * *(5.645)$ & $0.980 * * *(0.341)$ & 0.022 \\
\hline & & Weekend days & 17,536 & $398.10(264.55)$ & $-26.251 * * *(9.356)$ & $1.314 * * *(0.494)$ & 0.036 \\
\hline (I) & & Couple Only Time & 34,001 & 98.11(174.16) & $-8.769 * *(3.395)$ & $0.511^{* *}(0.233)$ & 0.045 \\
\hline
\end{tabular}


Table 2. Parents' Time with Children (in Minutes)

\begin{tabular}{|c|c|c|c|c|c|c|}
\hline \multicolumn{7}{|c|}{ Panel 1: Mothers $(\mathrm{N}=18,066)$} \\
\hline & \multicolumn{2}{|c|}{$\begin{array}{l}\text { Total Time with } \\
\text { Children }\end{array}$} & \multicolumn{2}{|c|}{$\begin{array}{c}\text { Enriching Time with } \\
\text { Children }\end{array}$} & \multicolumn{2}{|c|}{$\begin{array}{l}\text { Enriching Time Alone } \\
\text { with Children }\end{array}$} \\
\hline & (1) & (2) & (3) & (4) & (5) & (6) \\
\hline \multirow[t]{2}{*}{ Urate } & 1.593 & 1.618 & 0.400 & 2.091 & 0.747 & -3.945 \\
\hline & $(2.823)$ & $(8.248)$ & (1.159) & $(3.907)$ & $(0.936)$ & $(4.051)$ \\
\hline \multirow[t]{2}{*}{ Urate $^{2}$} & & -0.002 & & -0.101 & & 0.292 \\
\hline & & $(0.534)$ & & $(0.240)$ & & $(0.235)$ \\
\hline $\mathrm{R}^{2}$ & 0.233 & 0.233 & 0.078 & 0.078 & 0.064 & 0.064 \\
\hline Mean (SD) & \multicolumn{2}{|c|}{359.38 (306.27) } & \multicolumn{2}{|c|}{$56.97(95.49)$} & \multicolumn{2}{|c|}{$37.38(85.34)$} \\
\hline
\end{tabular}

Panel 2: Fathers $(\mathrm{N}=15,935)$

Total Time with Enriching Time with Enriching Time Alone Children Children with Children

\begin{tabular}{lcccccc} 
& $(1)$ & $(2)$ & $(3)$ & $(4)$ & $(5)$ & $(6)$ \\
\cline { 2 - 7 } Urate & 0.260 & -5.143 & 1.228 & 1.691 & $1.000^{* *}$ & 1.514 \\
& $(2.110)$ & $(7.893)$ & $(0.890)$ & $(3.164)$ & $(0.425)$ & $(1.442)$ \\
\multirow{2}{*}{ Urate $^{2}$} & & 0.319 & & -0.027 & & -0.030 \\
& & $(0.418)$ & & $(0.201)$ & & $(0.075)$ \\
$\mathrm{R}^{2}$ & 0.087 & 0.087 & 0.048 & 0.048 & 0.034 & 0.034 \\
Mean (SD) & $242.11(251.78)$ & $39.83(86.21)$ & $18.95(54.99)$
\end{tabular}

Notes: Sample includes only couples with co-resident children under age 19. Unemployment rates are measured at the state-level and all specifications include state fixed effects. ATUS final weights used. Standard errors adjusted for clustering by state are reported in parentheses. $\quad * * *$ significant at $1 \%$; **significant at 5\%; *significant at $10 \%$. Control variables include own and spouse's age and age squared, and indicators for husband and wife education (high school dropout, some college, college, missing), race and ethnicity (non-Hispanic black, other, Hispanic), age of youngest HH child (infant, preschooler, elementary), HH child older than age 18, live with other adults, gender composition of the children (all boy, mixed gender), season, lives in an SMSA, and year FEs. 
Table 3. Fathers' Time with Children Doing Enriching and Non-Enriching Activities (in minutes)

\begin{tabular}{|c|c|c|c|c|c|c|c|c|c|c|}
\hline \multicolumn{11}{|c|}{ Panel 1. Fathers' Total Time with Children $(\mathrm{N}=15,935)$} \\
\hline & \multicolumn{2}{|c|}{$\begin{array}{l}\text { Reading and } \\
\text { Homework }\end{array}$} & \multicolumn{2}{|c|}{ Playing } & \multicolumn{2}{|c|}{$\begin{array}{c}\text { Sports and Sporting } \\
\text { Events }\end{array}$} & \multicolumn{2}{|c|}{$\begin{array}{c}\text { Other Enriching } \\
\text { Activities }\end{array}$} & \multicolumn{2}{|c|}{$\begin{array}{c}\text { Non-Enriching } \\
\text { Activities }\end{array}$} \\
\hline & (1) & (2) & (3) & (4) & (5) & (6) & (7) & (8) & (9) & (10) \\
\hline Urate & $\begin{array}{c}0.066 \\
(0.202)\end{array}$ & $\begin{array}{c}0.624 \\
(0.746)\end{array}$ & $\begin{array}{l}0.885^{*} \\
(0.501)\end{array}$ & $\begin{array}{c}1.015 \\
(1.959)\end{array}$ & $\begin{array}{c}0.500 \\
(0.362)\end{array}$ & $\begin{array}{c}0.407 \\
(1.023)\end{array}$ & $\begin{array}{l}-0.223 \\
(0.538)\end{array}$ & $\begin{array}{l}-0.356 \\
(1.996)\end{array}$ & $\begin{array}{l}-0.968 \\
(1.913)\end{array}$ & $\begin{array}{l}-6.834 \\
(6.523)\end{array}$ \\
\hline Urate $^{2}$ & & $\begin{array}{c}-0.033 \\
(0.038)\end{array}$ & & $\begin{array}{c}-0.008 \\
(0.127)\end{array}$ & & $\begin{array}{c}0.005 \\
(0.049)\end{array}$ & & $\begin{array}{c}0.008 \\
(0.110)\end{array}$ & & $\begin{array}{c}0.346 \\
(0.343)\end{array}$ \\
\hline & 0.050 & 0.050 & 0.112 & 0.112 & 0.017 & 0.017 & 0.013 & 0.014 & 0.148 & 0.148 \\
\hline Mean (SD) & \multicolumn{2}{|c|}{$4.87(20.80)$} & \multicolumn{2}{|c|}{$16.09(56.90)$} & \multicolumn{2}{|c|}{$7.39(41.71)$} & \multicolumn{2}{|c|}{$11.49(66.92)$} & \multicolumn{2}{|c|}{$202.28(226.77)$} \\
\hline
\end{tabular}

Panel 2. Fathers' Time Alone with Children $(\mathrm{N}=15,935)$

\begin{tabular}{|c|c|c|c|c|c|c|c|c|c|c|}
\hline & \multicolumn{2}{|c|}{$\begin{array}{l}\text { Reading and } \\
\text { Homework }\end{array}$} & \multicolumn{2}{|c|}{ Playing } & \multicolumn{2}{|c|}{$\begin{array}{c}\text { Sports and Sporting } \\
\text { Events } \\
\end{array}$} & \multicolumn{2}{|c|}{$\begin{array}{c}\text { Other Enriching } \\
\text { Activities }\end{array}$} & \multicolumn{2}{|c|}{$\begin{array}{c}\text { Non-Enriching } \\
\text { Activities } \\
\end{array}$} \\
\hline & $(1)$ & (2) & (3) & (4) & (5) & (6) & $(7)$ & (8) & (9) & $(10)$ \\
\hline Urate & $\begin{array}{l}-0.019 \\
(0.154)\end{array}$ & $\begin{array}{l}1.439 * * \\
(0.614)\end{array}$ & $\begin{array}{c}0.480 \\
(0.357)\end{array}$ & $\begin{array}{l}-0.391 \\
(1.126)\end{array}$ & $\begin{array}{l}0.680^{* *} \\
(0.290)\end{array}$ & $\begin{array}{c}0.369 \\
(0.682)\end{array}$ & $\begin{array}{l}-0.117 \\
(0.245)\end{array}$ & $\begin{array}{c}0.194 \\
(0.711)\end{array}$ & $\begin{array}{l}-0.160 \\
(1.304)\end{array}$ & $\begin{array}{l}-4.788 \\
(3.491)\end{array}$ \\
\hline Urate $^{2}$ & & $\begin{array}{c}-0.086 * * * \\
(0.029)\end{array}$ & & $\begin{array}{c}0.051 \\
(0.057)\end{array}$ & & $\begin{array}{c}0.803 \\
(0.035)\end{array}$ & & $\begin{array}{c}-0.018 \\
(0.041)\end{array}$ & & $\begin{array}{c}0.273 \\
(0.192)\end{array}$ \\
\hline & 0.025 & 0.026 & 0.041 & 0.041 & 0.015 & 0.015 & 0.008 & 0.008 & 0.036 & \\
\hline Mean (SD) & \multicolumn{2}{|c|}{3.29 (18.57) } & $8.57(39$ & ) (41.05) & \multicolumn{2}{|c|}{3.85 (27.31) } & \multicolumn{2}{|c|}{3.24 (22.23) } & \multicolumn{2}{|c|}{65.08 (128.99) } \\
\hline
\end{tabular}

Notes: See Table 2. 
Table 4. Fathers' Time with Children by Earner Status and Education

\begin{tabular}{|c|c|c|c|c|c|c|}
\hline \multicolumn{7}{|c|}{ Panel 1. Fathers' All Time with Children $(\mathrm{N}=15,935)$} \\
\hline & \multicolumn{2}{|c|}{$\begin{array}{c}\text { Dual-Earner } \\
\text { Couple }\end{array}$} & \multicolumn{2}{|c|}{ No College } & \multicolumn{2}{|c|}{ College Degree } \\
\hline & (1) & (2) & (3) & (4) & (5) & (6) \\
\hline \multirow[t]{2}{*}{ Urate } & -3.178 & 7.053 & 1.160 & -14.331 & -0.866 & 9.900 \\
\hline & $(2.794)$ & $(9.644)$ & $(2.877)$ & $(10.118)$ & $(2.838)$ & $(11.621)$ \\
\hline \multirow[t]{2}{*}{ Urate $^{2}$} & & -0.613 & & $0.917^{*}$ & & -0.631 \\
\hline & & $(0.524)$ & & $(0.512)$ & & $(0.619)$ \\
\hline $\mathrm{R}^{2}$ & 0.098 & 0.098 & 0.090 & 0.090 & 0.091 & 0.091 \\
\hline $\mathrm{N}$ & \multicolumn{2}{|c|}{9,799} & \multicolumn{2}{|c|}{9,340} & \multicolumn{2}{|c|}{6,595} \\
\hline Mean (SD) & \multicolumn{2}{|c|}{$232.27(223.26)$} & \multicolumn{2}{|c|}{$236.24(250.34)$} & \multicolumn{2}{|c|}{$252.91(250.24)$} \\
\hline \multicolumn{7}{|c|}{ Panel 2. Fathers' Enriching Time Alone with Children $(N=15,935)$} \\
\hline & \multicolumn{2}{|c|}{$\begin{array}{c}\text { Dual-Earner } \\
\text { Couple }\end{array}$} & \multicolumn{2}{|c|}{ No College } & \multicolumn{2}{|c|}{ College Degree } \\
\hline & (1) & (2) & (3) & (4) & (5) & (6) \\
\hline \multirow[t]{2}{*}{ Urate } & $1.118^{*}$ & $5.233 * * *$ & $1.683^{* *}$ & -0.110 & 0.217 & $4.470^{*}$ \\
\hline & $(0.604)$ & $(1.897)$ & $(0.644)$ & $(2.277)$ & $(0.775)$ & $(2.272)$ \\
\hline \multirow[t]{2}{*}{ Urate $^{2}$} & & $-0.246^{* *}$ & & 0.106 & & $-0.249 * *$ \\
\hline & & $(0.106)$ & & $(0.114)$ & & $(0.109)$ \\
\hline $\mathrm{R}^{2}$ & 0.040 & 0.040 & 0.034 & 0.034 & 0.051 & 0.051 \\
\hline $\mathrm{N}$ & \multicolumn{2}{|c|}{9,799} & \multicolumn{2}{|c|}{9,340} & \multicolumn{2}{|c|}{6,595} \\
\hline Mean (SD) & \multicolumn{2}{|c|}{$19.02(60.73)$} & \multicolumn{2}{|c|}{$17.28(55.40)$} & \multicolumn{2}{|c|}{22.02 (54.91) } \\
\hline
\end{tabular}

Notes: See Table 2. 
Table 5. Time and Timing of Work

Panel 1: Mothers' Work Patterns $(N=18,066)$

\begin{tabular}{|c|c|c|c|c|c|c|c|c|c|c|}
\hline & \multicolumn{2}{|c|}{ ALL DAYS } & \multicolumn{6}{|c|}{ WEEKDAY } & \multicolumn{2}{|c|}{ WEEKEND DAY } \\
\hline & $\begin{array}{c}\text { Pr(Empl } \\
\text { oyed) }\end{array}$ & $\begin{array}{l}\text { Minutes } \\
\text { Worked }\end{array}$ & $\begin{array}{l}\text { Minutes } \\
\text { Worked }\end{array}$ & $\begin{array}{c}\text { Pr(Worked } \\
\text { 4am-8am) }\end{array}$ & $\begin{array}{l}\text { Pr(Worked } \\
\text { 8am- 2pm) }\end{array}$ & $\begin{array}{c}\text { Pr(Worked } \\
\text { 2pm-6pm) }\end{array}$ & $\begin{array}{c}\text { Pr(Worked } \\
6 p m-9 p m)\end{array}$ & $\begin{array}{c}\text { Pr(Worked } \\
\text { 9pm-4am) }\end{array}$ & Pr(Worked) & $\begin{array}{l}\text { Minutes } \\
\text { Worked }\end{array}$ \\
\hline & (1) & (2) & (3) & (4) & (5) & (6) & (7) & (8) & (9) & (10) \\
\hline \multirow[t]{2}{*}{ Urate $<4$} & 0.023 & -1.218 & -0.723 & 0.016 & 0.006 & 0.008 & -0.008 & -0.013 & -0.006 & 4.748 \\
\hline & $(0.015)$ & $(13.776)$ & $(10.300)$ & $(0.017)$ & $(0.033)$ & $(0.031)$ & $(0.014)$ & $(0.012)$ & $(0.020)$ & (28.777) \\
\hline \multirow[t]{2}{*}{ Urate 6-8 } & 0.002 & -4.929 & -0.505 & 0.005 & 0.006 & 0.015 & -0.003 & -0.005 & 0.020 & -7.620 \\
\hline & $(0.012)$ & $(9.625)$ & $(9.804)$ & $(0.014)$ & $(0.018)$ & $(0.015)$ & $(0.008)$ & $(0.005)$ & $(0.012)$ & (16.014) \\
\hline \multirow[t]{2}{*}{ Urate 8-10 } & 0.003 & -10.965 & 7.603 & 0.017 & -0.013 & -0.025 & 0.011 & 0.015 & $0.049 *$ & -23.718 \\
\hline & $(0.024)$ & (14.513) & (12.717) & $(0.024)$ & $(0.035)$ & $(0.033)$ & $(0.021)$ & $(0.013)$ & $(0.029)$ & (34.119) \\
\hline \multirow[t]{2}{*}{ Urate $10+$} & -0.044 & $-35.612^{*}$ & -21.263 & -0.001 & $-0.076^{*}$ & $-0.092 * *$ & 0.012 & -0.003 & 0.055 & -22.209 \\
\hline & $(0.032)$ & (17.895) & (18.944) & $(0.032)$ & $(0.043)$ & $(0.040)$ & $(0.021)$ & $(0.014)$ & $(0.033)$ & $(40.400)$ \\
\hline $\mathrm{R}^{2}$ & 0.105 & 0.020 & 0.047 & 0.044 & 0.080 & 0.072 & 0.025 & 0.023 & 0.027 & 0.194 \\
\hline $\begin{array}{l}\text { Mean } \\
\text { (SD) }\end{array}$ & 0.68 & $\begin{array}{c}269.81 \\
(296.61)\end{array}$ & $\begin{array}{c}437.01 \\
(165.55)\end{array}$ & 0.10 & 0.42 & 0.37 & 0.06 & 0.03 & 0.20 & $\begin{array}{c}269.51 \\
(253.68)\end{array}$ \\
\hline $\mathrm{N}$ & 18,066 & 12,378 & 4,833 & 8,809 & 8,809 & 8,809 & 8,809 & 8,809 & 9,257 & 1,900 \\
\hline
\end{tabular}

Notes: Sample includes only couples with co-resident children under age 19. Unemployment rates are measured at the state-level and all specifications include state and year fixed effects. ATUS final weights used. Standard errors adjusted for clustering by state are reported in parentheses. $\quad * * *$ significant at $1 \%$; **significant at $5 \%$; *significant at $10 \%$. Control variables include own and spouse's age and age squared, and indicators for husband and wife education (high school dropout, some college, college, missing), race and ethnicity (non-Hispanic black, other, Hispanic), age of youngest HH child (infant, preschooler, elementary), HH child older than age 18, live with other adult, gender composition of the children (all boy, mixed gender), season, and lives in an SMSA. The timing of work in columns (4)-(9) is defined as 1 if participating at least 60 minutes in the time slot or on the weekend in a workplace, and zero otherwise. Minutes of work exclude job search time and are included only for those who worked. Minutes of work in column 2 are conditional upon being employed and include zero time working on the diary day. Minutes of work in columns 3 and 10 are conditional upon having positive minutes of work on the diary day. 
Table 5. Time and Timing of Work (continued)

Panel 2: Fathers' Work Patterns $(N=15,935)$

\begin{tabular}{|c|c|c|c|c|c|c|c|c|c|c|}
\hline & \multicolumn{2}{|c|}{ ALL DAYS } & \multicolumn{6}{|c|}{ WEEKDAY } & \multicolumn{2}{|c|}{ WEEKEND DAY } \\
\hline & $\begin{array}{c}\operatorname{Pr}(\text { Empl } \\
\text { oyed) }\end{array}$ & $\begin{array}{l}\text { Minutes } \\
\text { Worked }\end{array}$ & $\begin{array}{l}\text { Minutes } \\
\text { Worked }\end{array}$ & $\begin{array}{c}\text { Pr(Worked } \\
\text { 4am-8am) }\end{array}$ & $\begin{array}{l}\text { Pr(Worked } \\
\text { 8am- 2pm) }\end{array}$ & $\begin{array}{l}\text { Pr(Worked } \\
\text { 2pm-6pm) }\end{array}$ & $\begin{array}{c}\text { Pr(Worked } \\
6 p m-9 p m)\end{array}$ & $\begin{array}{c}\text { Pr(Worked } \\
\text { 9pm-4am) }\end{array}$ & Pr(Worked) & $\begin{array}{l}\text { Minutes } \\
\text { Worked }\end{array}$ \\
\hline & (1) & (2) & (3) & (4) & (4) & (6) & (7) & (8) & (9) & (10) \\
\hline \multirow[t]{2}{*}{ Urate $<4$} & -0.006 & 6.155 & -11.180 & -0.020 & 0.013 & 0.041 & 0.022 & 0.008 & -0.055 & -0.453 \\
\hline & $(0.009)$ & $(15.910)$ & $(10.712)$ & $(0.023)$ & $(0.028)$ & $(0.033)$ & $(0.020)$ & $(0.016)$ & $(0.034)$ & $(28.504)$ \\
\hline \multirow[t]{2}{*}{ Urate 6-8 } & -0.005 & -10.706 & -9.702 & 0.010 & 0.002 & 0.009 & -0.004 & -0.015 & -0.014 & $43.476^{* * *}$ \\
\hline & $(0.010)$ & (6.923) & (6.383) & $(0.014)$ & $(0.022)$ & $(0.020)$ & $(0.016)$ & $(0.011)$ & $(0.018)$ & (14.804) \\
\hline \multirow[t]{2}{*}{ Urate 8-10 } & 0.021 & 1.590 & -17.937 & $0.067 *$ & 0.025 & 0.012 & -0.033 & -0.027 & 0.006 & 40.195 \\
\hline & $(0.019)$ & $(15.602)$ & (12.842) & $(0.038)$ & $(0.035)$ & $(0.035)$ & $(0.023)$ & $(0.021)$ & $(0.036)$ & (37.058) \\
\hline \multirow[t]{2}{*}{ Urate 10+ } & -0.037 & -2.720 & -19.238 & 0.055 & -0.038 & -0.029 & -0.030 & -0.024 & 0.027 & $72.357 * *$ \\
\hline & $(0.028)$ & $(17.978)$ & $(19.585)$ & $(0.049)$ & $(0.044)$ & $(0.043)$ & $(0.023)$ & $(0.022)$ & $(0.049)$ & $(30.982)$ \\
\hline $\mathrm{R}^{2}$ & 0.076 & 0.010 & 0.023 & 0.068 & 0.042 & 0.048 & 0.022 & 0.028 & 0.024 & 0.149 \\
\hline $\begin{array}{l}\text { Mean } \\
(\mathrm{SD})\end{array}$ & 0.91 & $\begin{array}{l}361.14 \\
(298.23)\end{array}$ & $\begin{array}{c}518.10 \\
(181.01)\end{array}$ & 0.31 & 0.68 & 0.62 & 0.12 & 0.07 & 0.34 & $\begin{array}{c}328.46 \\
(283.60)\end{array}$ \\
\hline $\mathrm{N}$ & 15,935 & 14,639 & 6,347 & 7,656 & 7,656 & 7,656 & 7,656 & 7,656 & 8,279 & 2,834 \\
\hline
\end{tabular}

Notes: Sample includes only couples with co-resident children under age 19. Unemployment rates are measured at the state-level and all specifications include state and year fixed effects. ATUS final weights used. Standard errors adjusted for clustering by state are reported in parentheses. $\quad * * *$ significant at $1 \%$; **significant at $5 \%$; *significant at $10 \%$. Control variables include own and spouse's age and age squared, and indicators for husband and wife education (high school dropout, some college, college, missing), race and ethnicity (non-Hispanic black, other, Hispanic), age of youngest HH child (infant, preschooler, elementary), HH child older than age 18, live with other adult, gender composition of the children (all boy, mixed gender), season, and lives in an SMSA. The timing of work in columns (4)-(9) is defined as 1 if participating at least 60 minutes in the time slot or on the weekend in a workplace, and zero otherwise. Minutes of work exclude job search time and are included only for those who worked. Minutes of work in column 2 are conditional upon being employed and include zero time working on the diary day. Minutes of work in columns 3 and 10 are conditional upon having positive minutes of work on the diary day. 


\begin{tabular}{lc}
\hline Married and cohabitating individuals & $\begin{array}{c}\text { Number of } \\
\text { Observations }\end{array}$ \\
$\begin{array}{l}\text { Married and cohabitating individuals in heterosexual } \\
\text { relationships }\end{array}$ & 60,923 \\
Married and cohabitating individuals aged 25-64 in & 60,636 \\
heterosexual couples & 48,749 \\
$\begin{array}{l}\text { Married and cohabitating individuals aged 25-64 in } \\
\text { heterosexual couples with household children under age 19 }\end{array}$ & 34,153 \\
$\begin{array}{l}\text { Drop those who slept more than 20 hours on diary day } \\
\text { Drop those sick more than 4 hours on diary day }\end{array}$ & 34,137 \\
\hline
\end{tabular}


Table A2. Time Use Variables Created from the ATUS Diaries

\begin{tabular}{|c|c|}
\hline Variable & Definition \\
\hline \multicolumn{2}{|c|}{ Enriching childcare (children of all ages) } \\
\hline 30102 & Reading to/with household children \\
\hline 30103 & Playing with household children, not sports \\
\hline 30104 & Arts and crafts with household children \\
\hline 30105 & Playing sports with household children \\
\hline 30106 & Talking with/listening to household children \\
\hline 30107 & Helping/teaching household children (not related to education) \\
\hline 30201 & Homework (household children) \\
\hline 30203 & Home schooling of household children \\
\hline \multicolumn{2}{|c|}{ Enriching childcare (children aged 2+) } \\
\hline 1201 & Socializing and communicating \\
\hline 120307 & Playing games \\
\hline 120309 & Arts and crafts as a hobby \\
\hline 120310 & Collecting as a hobby \\
\hline 120311 & Hobbies, except arts \& crafts and collecting \\
\hline 120401 & Attending performances \\
\hline 120402 & Attending museums \\
\hline 120403 & Attending movies/films \\
\hline 1301 & Participating in sports \\
\hline 1302 & Attending sporting events \\
\hline \multicolumn{2}{|c|}{ Reading and homework } \\
\hline 30102 & Reading to/with household children \\
\hline 30201 & Homework (household children) \\
\hline 30203 & Home schooling of household children \\
\hline \multicolumn{2}{|r|}{ ( } \\
\hline 30103 & Playing with household children, not sports \\
\hline 30104 & Arts and crafts with household children \\
\hline 120307 & Playing games (children aged 2+) \\
\hline 120309 & Arts and crafts as a hobby (children aged $2+$ ) \\
\hline \multicolumn{2}{|c|}{ Sports and sporting events } \\
\hline 30105 & Playing sports with household children \\
\hline 1301 & Participating in sports (children aged 2+) \\
\hline 1302 & Attending sporting events (children aged 2+) \\
\hline
\end{tabular}


Table A3. Mean Characteristics

\begin{tabular}{|c|c|c|c|}
\hline & $\begin{array}{l}\text { Couple } \\
\text { Sample }\end{array}$ & $\begin{array}{l}\text { Mother } \\
\text { Sample }\end{array}$ & $\begin{array}{l}\text { Father } \\
\text { Sample }\end{array}$ \\
\hline \multicolumn{4}{|l|}{ Economic conditions: } \\
\hline State yearly unemployment rate & 6.09 & 6.08 & 6.11 \\
\hline [overall min 2.45, max 14.86] & (1.99) & $(1.95)$ & $(1.96)$ \\
\hline \multicolumn{4}{|l|}{ Time together: } \\
\hline \multirow{2}{*}{ Time with Spouse } & 248.81 & 239.05 & 258.53 \\
\hline & $(247.63)$ & $(250.25)$ & $(254.82)$ \\
\hline \multirow[t]{2}{*}{ All Time with Children } & 300.57 & 359.38 & 242.11 \\
\hline & (297.99) & $(306.27)$ & $(251.78)$ \\
\hline \multirow[t]{2}{*}{ Enriching Time with Children } & 48.37 & 56.97 & 39.83 \\
\hline & $(90.83)$ & $(95.49)$ & $(86.21)$ \\
\hline \multirow[t]{2}{*}{ Enriching Time with Children Alone } & 28.14 & 37.38 & 18.95 \\
\hline & $(72.72)$ & $(85.34)$ & $(54.99)$ \\
\hline \multicolumn{4}{|l|}{ Individual characteristics: } \\
\hline Hispanic & 0.18 & 0.18 & 0.18 \\
\hline Non-Hispanic black & 0.08 & 0.07 & 0.09 \\
\hline Non-Hispanic other & 0.06 & 0.06 & 0.06 \\
\hline \multirow[t]{2}{*}{ Age } & 40.03 & 38.96 & 41.09 \\
\hline & $(9.25)$ & $(8.96)$ & $(10.28)$ \\
\hline \multirow[t]{2}{*}{ Spouse's age } & 40.19 & 41.33 & 39.05 \\
\hline & $(9.99)$ & $(10.18)$ & $(9.91)$ \\
\hline Wife HS dropout & 0.11 & 0.11 & 0.11 \\
\hline Wife some college & 0.27 & 0.27 & 0.27 \\
\hline Wife college & 0.36 & 0.36 & 0.37 \\
\hline Husband HS dropout & 0.12 & 0.12 & 0.12 \\
\hline Husband some college & 0.24 & 0.25 & 0.23 \\
\hline Husband college & 0.35 & 0.35 & 0.35 \\
\hline Wife missing education & 0.00 & 0.00 & 0.005 \\
\hline Husband missing education & 0.004 & 0.01 & 0.00 \\
\hline Youngest child infant & 0.26 & 0.27 & 0.26 \\
\hline Youngest child preschooler & 0.19 & 0.18 & 0.19 \\
\hline Youngest child elementary student & 0.33 & 0.33 & 0.33 \\
\hline Two children in household & 0.40 & 0.40 & 0.41 \\
\hline Three or more children in household & 0.24 & 0.24 & 0.24 \\
\hline Cohabitating & 0.04 & 0.04 & 0.04 \\
\hline Child older than 18 in $\mathrm{HH}$ & 0.13 & 0.14 & 0.13 \\
\hline Live with other adults & 0.06 & 0.06 & 0.06 \\
\hline All boy HH children & 0.31 & 0.32 & 0.31 \\
\hline Mixed gender $\mathrm{HH}$ children & 0.40 & 0.39 & 0.39 \\
\hline Resides in SMSA & 0.83 & 0.83 & 0.83 \\
\hline Wife employed & 0.67 & 0.68 & 0.66 \\
\hline Husband employed & 0.91 & 0.91 & 0.91 \\
\hline $\mathrm{N}$ & 34,001 & 18,066 & 15,935 \\
\hline
\end{tabular}

Notes: Survey weights used. Standard deviations are in parentheses. 


\section{Appendix Table A4. OLS Estimates}

Urate

Urate $^{2}$

Hispanic

Black

Other race

Age

Age squared

Spouse’s age

Spouse’s age squared

Wife HS dropout

Wife some college

Wife college

Husband HS dropout

Husband some college

Husband college

Wife college missing

Husband college missing

Youngest child is infant

Youngest child is preschooler

Youngest child elementary-school aged

\begin{tabular}{|c|c|c|}
\hline $\begin{array}{c}\text { Parents’ Time } \\
\text { Together } \\
(\mathrm{N}=34,001)\end{array}$ & $\begin{array}{l}\text { Mother's } \\
\text { Enriching } \\
\text { Alone Time } \\
(\mathrm{N}=18,066)\end{array}$ & $\begin{array}{c}\text { Father's } \\
\text { Enriching } \\
\text { Alone Time } \\
(\mathrm{N}=15,935)\end{array}$ \\
\hline$(1)$ & $(2)$ & (3) \\
\hline $\begin{array}{c}-18.355^{* * * *} \\
(6.090)\end{array}$ & $\begin{array}{c}0.747 \\
(0.936)\end{array}$ & $\begin{array}{c}1.000 * * \\
(0.425)\end{array}$ \\
\hline $\begin{array}{c}1.050 * * * \\
(0.378)\end{array}$ & & \\
\hline $\begin{array}{c}-0.748 \\
(5.430)\end{array}$ & $\begin{array}{c}-7.699 * * * \\
(1.831)\end{array}$ & $\begin{array}{c}-4.445^{* * *} \\
(1.018)\end{array}$ \\
\hline$-45.439 * * *$ & $-12.432 * * *$ & $-2.876 * *$ \\
\hline (6.368) & (2.415) & $(1.357)$ \\
\hline-4.057 & -1.172 & -3.025 \\
\hline (4.804) & (3.501) & $(2.160)$ \\
\hline-2.245 & $2.083 * *$ & $1.437 * *$ \\
\hline (2.529) & $(0.990)$ & $(0.708)$ \\
\hline 19.091 & $-31.547 * * *$ & $-18.445^{* *}$ \\
\hline (28.551) & (11.219) & (7.778) \\
\hline$-3.939 *$ & 0.206 & 0.016 \\
\hline (1.979) & (1.114) & $(0.677)$ \\
\hline $4.024^{*}$ & -0.269 & -0.223 \\
\hline (2.171) & (1.239) & $(0.816)$ \\
\hline $20.005 * * *$ & -0.089 & -1.611 \\
\hline$(5.840)$ & (3.060) & (2.418) \\
\hline-4.859 & -0.681 & 1.076 \\
\hline (5.086) & (1.362) & (1.526) \\
\hline-9.071 & 1.017 & 3.127 \\
\hline (5.451) & (1.514) & (1.991) \\
\hline-2.345 & -0.474 & $-3.890 * *$ \\
\hline (5.685) & $(2.847)$ & (1.788) \\
\hline 0.511 & 1.157 & 0.816 \\
\hline (4.306) & (1.390) & $(1.236)$ \\
\hline $11.427^{* *}$ & $6.341 * * *$ & 1.508 \\
\hline$(5.020)$ & $(1.446)$ & (1.608) \\
\hline-40.815 & 0.000 & 5.329 \\
\hline (24.804) & $(0.000)$ & (8.906) \\
\hline-36.344 & -1.031 & 0.000 \\
\hline (26.986) & (7.927) & $(0.000)$ \\
\hline $19.574 * * *$ & $31.676 * * *$ & $11.151 * * *$ \\
\hline$(5.554)$ & $(2.355)$ & $(1.892)$ \\
\hline-2.533 & $23.607 * * *$ & $15.559 * * *$ \\
\hline (6.310) & $(2.272)$ & (1.643) \\
\hline-4.508 & $11.675 * * *$ & $7.071 * * *$ \\
\hline (5.064) & $(1.406)$ & $(1.254)$ \\
\hline
\end{tabular}




\begin{tabular}{|c|c|c|c|}
\hline Two children in household & $\begin{array}{l}-2.993 \\
(3.513)\end{array}$ & $\begin{array}{c}2.584 \\
(1.611)\end{array}$ & $\begin{array}{c}1.584 \\
(1.118)\end{array}$ \\
\hline Three or more children in & -2.219 & $7.211^{* * *}$ & $3.905^{* *}$ \\
\hline household & $(4.842)$ & $(1.796)$ & (1.915) \\
\hline Winter & $\begin{array}{c}12.528 * * * \\
(4.286)\end{array}$ & $\begin{array}{c}-2.570 * * \\
(1.227)\end{array}$ & $\begin{array}{c}1.636 \\
(1.297)\end{array}$ \\
\hline Spring & $\begin{array}{l}-0.843 \\
(4.290)\end{array}$ & $\begin{array}{l}-0.986 \\
(1.555)\end{array}$ & $\begin{array}{l}-0.185 \\
(1.083)\end{array}$ \\
\hline Summer & $\begin{array}{l}14.300^{* * *} \\
(5.075)\end{array}$ & $\begin{array}{c}1.597 \\
(1.632)\end{array}$ & $\begin{array}{c}2.534^{* *} \\
(1.076)\end{array}$ \\
\hline SMSA & $\begin{array}{l}-3.517 \\
(4.389)\end{array}$ & $\begin{array}{c}1.830 \\
(1.606)\end{array}$ & $\begin{array}{c}0.728 \\
(1.401)\end{array}$ \\
\hline Cohabitating couple & $\begin{array}{l}-5.061 \\
(8.259)\end{array}$ & $\begin{array}{c}-5.625^{* *} \\
(2.710)\end{array}$ & $\begin{array}{l}-1.734 \\
(2.611)\end{array}$ \\
\hline Child aged 19+ in household & $\begin{array}{l}-5.545 \\
(4.312)\end{array}$ & $\begin{array}{c}-3.485^{* *} \\
(1.706)\end{array}$ & $\begin{array}{c}0.098 \\
(1.681)\end{array}$ \\
\hline All boys in household & $\begin{array}{c}3.322 \\
(3.320)\end{array}$ & $\begin{array}{l}-0.530 \\
(1.273)\end{array}$ & $\begin{array}{c}6.257 * * * \\
(1.187)\end{array}$ \\
\hline $\begin{array}{l}\text { Mixed - gender children in } \\
\text { household }\end{array}$ & $\begin{array}{l}-2.384 \\
(3.998)\end{array}$ & $\begin{array}{c}1.228 \\
(1.437)\end{array}$ & $\begin{array}{c}3.791 * * * \\
(1.269)\end{array}$ \\
\hline Other adults in household & $\begin{array}{l}-8.938 \\
(8.271)\end{array}$ & $\begin{array}{c}-4.732 \\
(3.684)\end{array}$ & $\begin{array}{l}-3.606 \\
(2.201)\end{array}$ \\
\hline Female & $\begin{array}{l}-20.940 * * * \\
(2.628)\end{array}$ & $\begin{array}{c}0.000 \\
(0.000)\end{array}$ & $\begin{array}{c}0.000 \\
(0.000)\end{array}$ \\
\hline Year $=2003$ & $\begin{array}{c}2.611 \\
(4.510)\end{array}$ & $\begin{array}{l}-0.834 \\
(2.201)\end{array}$ & $\begin{array}{l}-1.059 \\
(1.735)\end{array}$ \\
\hline Year $=2004$ & $\begin{array}{l}-5.052 \\
(4.415)\end{array}$ & $\begin{array}{c}2.249 \\
(2.168)\end{array}$ & $\begin{array}{c}1.471 \\
(2.004)\end{array}$ \\
\hline Year $=2006$ & $\begin{array}{l}-5.865 \\
(6.838)\end{array}$ & $\begin{array}{c}0.945 \\
(3.234)\end{array}$ & $\begin{array}{c}1.769 \\
(2.041)\end{array}$ \\
\hline Year $=2007$ & $\begin{array}{c}0.132 \\
(5.809)\end{array}$ & $\begin{array}{l}2.311 \\
(2.627)\end{array}$ & $\begin{array}{c}1.422 \\
(1.628)\end{array}$ \\
\hline Year $=2008$ & $\begin{array}{l}-0.121 \\
(5.181)\end{array}$ & $\begin{array}{l}-2.123 \\
(2.363)\end{array}$ & $\begin{array}{c}1.396 \\
(1.900)\end{array}$ \\
\hline Year $=2009$ & $\begin{array}{c}24.707^{* * *} \\
(6.286)\end{array}$ & $\begin{array}{l}-3.785 \\
(3.021)\end{array}$ & $\begin{array}{c}0.708 \\
(2.719)\end{array}$ \\
\hline Year $=2010$ & $\begin{array}{c}14.491^{* *} \\
(7.032)\end{array}$ & $\begin{array}{l}-3.805 \\
(4.105)\end{array}$ & $\begin{array}{l}-1.859 \\
(2.627)\end{array}$ \\
\hline Constant & $\begin{array}{c}467.462 * * * \\
(54.490)\end{array}$ & $\begin{array}{c}-8.718 \\
(27.415) \\
\end{array}$ & $\begin{array}{l}-18.949 \\
(16.667) \\
\end{array}$ \\
\hline
\end{tabular}

Notes: Column (1) is the full set of covariates from the quadratic specification in Table 1, full sample. Column (2) is the full set of covariates from the model in Panel 1 of Table 2 column 5, 'Mother's enriching time alone with children'. Column (3) is the full set of covariates from the model in Panel 2 of Table 2 column 5, 'Father's enriching time alone with children'.

Regressions also include state FEs. Standard errors adjusted for clustering by state are reported in parentheses. ${ }^{* * *} \mathrm{p}<0.01,{ }^{* *} \mathrm{p}<0.05,{ }^{*} \mathrm{p}<0.1$. 
Appendix A5. Married Couples with Children Time Together $(\mathrm{N}=34,001)$

\begin{tabular}{lc}
\hline & $\begin{array}{c}\text { Couple time } \\
\text { together }\end{array}$ \\
\hline Urate 2-4 & 4.292 \\
& $(9.487)$ \\
Urate 6-8 & -6.617 \\
& $(4.315)$ \\
Urate 8-10 & $-16.133^{*}$ \\
& $(8.701)$ \\
Urate 10+ & -1.245 \\
& $(12.781)$ \\
$\mathrm{R}^{2}$ & 0.017 \\
\hline
\end{tabular}

Notes: Sample includes only couples with co-resident children under age 19. Unemployment rates are measured at the state-level and all specifications include state and year fixed effects. The omitted category is a state unemployment rate of 4-6 percent. Standard errors adjusted for clustering by state are reported in parentheses. ${ }^{* * *}$ significant at $1 \%$; **significant at $5 \%$; *significant at $10 \%$. Control variables include own and spouse's age and age squared, and indicators for husband and wife education (high school dropout, some college, college, missing), race and ethnicity (non-Hispanic black, other, Hispanic), gender, age of youngest $\mathrm{HH}$ child (infant, preschooler, elementary), HH child older than age 18, lives with other adults, gender composition of the children (all boy, mixed gender), season, and respondent lives in SMSA. 